\title{
A High-Strain-Rate Superplasticity of the Al-Mg-Si-Zr-Sc Alloy with Ni Addition
}

\author{
Andrey Mochugovskiy, Anton Kotov (D, Majid Esmaeili Ghayoumabadi, Olga Yakovtseva (D) \\ and Anastasia Mikhaylovskaya *
}

check for updates

Citation: Mochugovskiy, A.; Kotov, A.; Esmaeili Ghayoumabadi, M.; Yakovtseva, O.; Mikhaylovskaya, A. A High-Strain-Rate Superplasticity of the Al-Mg-Si-Zr-Sc Alloy with Ni Addition. Materials 2021, 14, 2028. https://doi.org/10.3390/ma14082028

Academic Editor: Hideki Hosoda

Received: 3 March 2021

Accepted: 14 April 2021

Published: 17 April 2021

Publisher's Note: MDPI stays neutral with regard to jurisdictional claims in published maps and institutional affiliations.

Copyright: (c) 2021 by the authors. Licensee MDPI, Basel, Switzerland. This article is an open access article distributed under the terms and conditions of the Creative Commons Attribution (CC BY) license (https:// creativecommons.org/licenses/by/ $4.0 /)$.
Department of Physical Metallurgy of Non-Ferrous Metals, National University of Sciences and Technology "MISIS", 4 Leninskiy ave. 4, 119049 Moscow, Russia; mochugovskiy.ag@misis.ru (A.M.); kotov@misis.ru (A.K.); ilieamse_dijam@yahoo.com (M.E.G.); yakovtseva.oa@misis.ru (O.Y.)

* Correspondence: mihaylovskaya@misis.ru; Tel.: +7-(495)-6384480

\begin{abstract}
The current study analyzed the effect of Ni content on the microstructure and superplastic deformation behavior of the Al-Mg-Si-Cu-based alloy doped with small additions of Sc and Zr. The superplasticity was observed in the studied alloys due to a bimodal particle size distribution. The coarse particles of eutectic origin $\mathrm{Al}_{3} \mathrm{Ni}$ and $\mathrm{Mg}_{2} \mathrm{Si}$ phases with a total volume fraction of $4.0-8.0 \%$ and a mean size of 1.4-1.6 $\mu \mathrm{m}$ provided the particles with a stimulated nucleation effect. $\mathrm{The} \mathrm{L} 1_{2}-$ structured nanoscale dispersoids of Sc- and Zr-bearing phase inhibited recrystallization and grain growth due to a strong Zener pinning effect. The positive effect of $\mathrm{Ni}$ on the superplasticity was revealed and confirmed by a high-temperature tensile test in a wide strain rate and temperature limits. In the alloy with $4 \mathrm{wt} . \% \mathrm{Ni}$, the elongation-to-failure of $350-520 \%$ was observed at $460{ }^{\circ} \mathrm{C}$, in a strain rate range of $2 \times 10^{-3}-5 \times 10^{-2} \mathrm{~s}^{-1}$.
\end{abstract}

Keywords: superplasticity; aluminum alloys; transition metals; dispersoids; particle-stimulated nucleation

\section{Introduction}

AA6XXX-type (Al-Mg-Si-based) alloys are widely applied for engineering applications [1,2], owing to their low density, high corrosion resistance, and increased mechanical properties at room temperature. The Al-Mg-Si-based alloys belong to the heat treatable group due to a significant strengthening effect, provided by $\beta^{\prime}, \beta^{\prime \prime}$-phases (metastable modifications of the $\mathrm{Mg}_{2} \mathrm{Si}$-phase), usually form during the ageing process [3-6]. Numerous commercial $6 \mathrm{XXX}$-type alloys contain $\mathrm{Cu}$ that improves strength owing to the formation of the metastable $\mathrm{Q}-(\mathrm{Al}, \mathrm{Mg}, \mathrm{Si}, \mathrm{Cu})$-type phase precipitates [3,7-9]. Due to the promising mechanical characteristics at room temperature and a low critical cooling rate for solid solution treatment, the Al-Mg-Si-based alloys are attractive for production of the complex-shaped parts by superplastic forming (SPF) technology. The superplasticity of $\mathrm{Al}-\mathrm{Mg}$-Si based alloys is poorly studied. The main problems of Al-Mg-Si based alloys are the difficulty of the grain refinement and the significant grain growth that caused the low strain rate sensitivity and weak superplasticity [10]. A comparatively low alloyed solid solution [11,12] is prone to the grain growth during heating up to the superplastic deformation temperature and during superplastic deformation that decrease an elongationto-failure [10], and led to the "orange peel" effect on the post-forming surface [13]. Some progresses in the field of superplasticity for the Al-Mg-Si based alloys have been made by Troeger and Stark [14,15]. The authors applied Rockwell-type technology, including heterogenization annealing [16] for the AA6061 alloy, to involve the particle stimulated nucleation (PSN) effect. The thermomechanical treatment provides fine-grained structure with a grain size of about $9 \mu \mathrm{m}$ and superplasticity with the elongation-to-failure of $375 \%$ at a strain rate of $5 \times 10^{-4} \mathrm{~s}^{-1}$. Moreover, a low strain rate is a cause of low SPF productivity. A significant progress in the grain refinement of Al-Mg-Si bases alloys was attained due to severe plastic deformation (SPD) techniques. A mean grain size of $0.24-4.5 \mu \mathrm{m}$, and 
superplasticity in a wide strain rate range of $1 \times 10^{-4}-5 \times 10^{-2} \mathrm{~s}^{-1}$ were achieved for the 6061 and 6063 alloys processed by equal-channel angular pressing and accumulative roll bonding, while the elongation-to-failure was 200-270\% [17-19]. Nevertheless, low elongation, which is the result of a significant grain growth, limits complex shaped parts production by SPF method. In addition, most of the SPD techniques cannot be conveniently applied for mass production, due to financial and technical aspects.

The modification of the alloys' composition is an effective way to provide a thermally stable fine-grained structure and a good superplasticity for various alloys [20]. In this case, the grain-refinement approach is based on the bimodal particle size distribution that can be arranged after a simple thermomechanical treatment [20]. Coarse particles provide grain refinement during recrystallization via particle-stimulated nucleation (PSN) effect $[16,21,22]$. Such coarse particles may precipitate during heterogenization treatment from a solid solution supersaturated by $\mathrm{Mg}, \mathrm{Zn}, \mathrm{Si}, \mathrm{Cu}[14,16,23]$, and precipitate during solidification due to alloying with eutectic forming elements, such as Ni, Fe, Mn, Ce [24-27]. Nickel is a promising alloying element for increasing the superplasticity of Al-based alloys [24,26-30]. The homogeneous distribution of the coarse $\mathrm{Al}_{3} \mathrm{Ni}$ particles with a near-spherical morphology is formed in the alloys' sheets during a simple thermomechanical treatment $[26,27,29]$. Fine dispersoids are formed due to alloying with rare-earth (RE) and transition metals (TM), such as $\mathrm{Zr}$, Sc, Mn, Cr, etc. Nanoscale dispersoids are precipitated during thermomechanical treatment from a supersaturated by TM/RE aluminum based solid solution [31-34]. Dispersoids cause Zener pinning effect and stabilize grain size [35-38]. The joint addition of $\mathrm{Sc}$ and $\mathrm{Zr}$ is the most effective dispersoids-forming combination. Sc and $\mathrm{Zr}$ provide the formation of a high density core-shell $\mathrm{L}_{2}$-strucured $\mathrm{Al}_{3}(\mathrm{Sc}, \mathrm{Zr})$ dispersoids [39-41]. These dispersoids result in strong Zener pining effect and inhibit grain growth, and, in addition, increase tensile properties at room temperature [42-48]. In novel alloys, the additions of Sc, as an expensive element, are reduced to $0.1 \mathrm{wt} . \%$, while that of $\mathrm{Zr}$ is retained in a higher amount, $0.2 \mathrm{wt} . \%[32,49,50]$. The bimodal distribution of the particles in the alloy's structure provides a high strain rate superplasticity with strain rate sensitivity coefficient $m$ above 0.3 for the AA5XXX- [24,30,51], AA7XXX- [29,30,42,52] and AA2XXX-types [27,34] alloys containing eutectic- and dispersoid-forming Fe [24], Ni [24,27,29,52], Ce [25,27,53], Y [34], $\operatorname{Er}[51], \mathrm{Mn}[54,55], \mathrm{Cr}[55], \mathrm{Zr}$ [30,56,57], Sc [58-61]. The influence of the eutectic-forming and dispersoid-forming elements on the grain structure and superplastic deformation behavior of Al-Mg-Si type alloys is poorly studied. The current work focuses on the analysis of the microstructural evolution and superplastic behavior of a novel Al-Mg-Si-based alloy with different content of eutectic forming $\mathrm{Ni}$ and small additives of dispersoid forming Sc and Zr.

\section{Materials and Methods}

A novel Al-Mg-Si-Cu-Ni-Zr-Sc alloy was studied. The concentrations of the alloying elements are shown in Table 1.

Table 1. Chemical composition of the studied alloys (wt.\%).

\begin{tabular}{ccccccccc}
\hline Alloy & $\mathbf{M g}$ & $\mathbf{S i}$ & $\mathbf{C u}$ & $\mathbf{N i}$ & $\mathbf{S c}$ & $\mathbf{Z r}$ & $\mathbf{F e}$ & $\mathbf{A l}$ \\
\hline Reference & 1.2 & 0.7 & 1.0 & 0 & 0.1 & 0.2 & $<0.01$ & balance \\
1 & 1.2 & 0.7 & 1.0 & 0.5 & 0.1 & 0.2 & $<0.01$ & balance \\
2 & 1.2 & 0.7 & 1.0 & 2.0 & 0.1 & 0.2 & $<0.01$ & balance \\
3 & 1.2 & 0.7 & 1.0 & 4.0 & 0.1 & 0.2 & $<0.01$ & balance \\
\hline
\end{tabular}

The alloys were prepared in a $20 \mathrm{~kW}$ induction furnace (Interselt, Saint-Petersburg, Russia) using graphite-fireclay crucibles (Lugaabrasiv, Luga, Russia). For the preparation of the alloys, the following pure metals and "master alloys" (UC Rusal, Moscow, Russia) were used: Al (99.99 wt.\%), Mg (99.96 wt.\%), Al-5 wt.\% Zr, Al-2 wt.\% Sc, Al-12 wt.\% Si, Al-53.5 wt.\% Cu, and Al-20 wt.\% Ni. The temperature was controlled by a chromel-alumel thermocouple. The temperature of the melt before casting was $830 \pm 10^{\circ} \mathrm{C}$. The casting was 
performed using water-cooled copper mold with a size of $100 \times 40 \times 20 \mathrm{~mm}^{3}$, providing the casting cooling rate of approximately $15 \mathrm{~K} / \mathrm{s}$.

The heat treatment of as-cast material plays the most important role for the dispersoid strengthening and grain boundary pinning effect. The high density of fine $\mathrm{L}_{2}$-strucutred Sc- and Zr-bearing dispersoids is observed after low temperature annealing [43,62-65] and two-step annealing regimes $[43,56,63,65-67]$. The homogenization annealing for the studied alloys was performed in two steps, with the first low-temperature step at $350{ }^{\circ} \mathrm{C}$ for $8 \mathrm{~h}$ and the second high-temperature step at $480^{\circ} \mathrm{C}$ for $3 \mathrm{~h}$ to provide precipitation of the $\mathrm{L}_{2}$ dispersoids and fragmentation and spheroidization of the $\mathrm{Al}_{3} \mathrm{Ni}$ particles $[29,52]$. The as-homogenized alloy was subjected to a hot rolling (Rolling mill V-3P, GMT, SaintPetersburg, Russia), with 85\% total reduction and subsequent cold rolling (Rolling mill V-3P, GMT, Saint-Petersburg, Russia),), with $65 \%$ total reduction to prepare sheets with a thickness of $1 \mathrm{~mm}$. The hot rolling was performed at $400 \pm 20^{\circ} \mathrm{C}$. The hot and cold rolling were performed in 6 and 10 passes, respectively.

The phase composition of the alloys in the as-cast state was controlled by X-ray diffraction (XRD) analysis, using Bruker D8 Advance diffractometer with $\mathrm{Cu}-\mathrm{K}_{\alpha}$ radiation (Bruker Corporation, Billerica, MA, USA).

The microstructural evolution was studied by electron scanning microscopy (SEM) and optical microscopy (OM). A Tescan-VEGA3 LMH electron microscope with a tungsten filament cathode (Tescan Brno s.r.o., Kohoutovice, Czech Republic) and an Oxford Instruments Advanced AZtecEnergy energy dispersive X-ray microanalysis system (EDS) (Oxford Instruments plc, Abingdon, UK) was used in the current study. Backscattered electron imaging (BSE) was performed with a $15 \mathrm{~mm}$ work distance and acceleration voltage of $20 \mathrm{kV}$. The grain structure of samples before the superplastic deformation was analyzed under a Carl Zeiss Axiovert 200M optical microscope (Carl Zeiss, Oberkochen, Germany) in a polarized light. The samples for OM and SEM analysis were prepared by mechanical grinding with subsequent polishing using the colloidal silica suspension Struers OP-U (Struers APS, Ballerup, Denmark). The samples for OM were subjected to anodic oxidation in a $10 \%$ water solution of the $\mathrm{H}_{3} \mathrm{BO}_{4}$ saturated in the HF.

The transmission electron microscopy (TEM) analysis was carried out using a JEOL JEM 2100 microscope (JEOL, Tokyo, Japan). The disc-shaped samples of $3 \mathrm{~mm}$ diameter and $0.18-0.25 \mathrm{~mm}$ thickness were used for TEM analysis. The samples were preliminarily subjected to a twin-jet electropolishing in a Struers TenuPol-6 system (Struers APS, Ballerup, Denmark) at $-25 \pm 5{ }^{\circ} \mathrm{C}$ using $30 \% \mathrm{HNO}_{3}$ methanol solution (Struers APS, Ballerup, Denmark).

The tensile test at elevated temperatures was performed using a Walter-Bai LFM 100 universal testing machine (Walter + Bai AG, Löhningen, Switzerland) in a temperature range of $440-500{ }^{\circ} \mathrm{C}$ and a constant strain rate range of $2 \times 10^{-3}-5 \times 10^{-2} \mathrm{~s}^{-1}$. Three samples with a gauge part size of $14 \times 6 \times 1 \mathrm{~mm}^{3}$ were used for each testing condition. The largest dimension of the gauge part was parallel to the rolling direction. The strain rate was maintained constant due to controlled increasing travers speed during the test. The strain rate sensitivity $m$ coefficient values were calculated as a first derivative of the logarithmically transformed Backofen equation for a strain of $50 \%$.

$$
m=\partial \ln \sigma / \partial \ln \dot{\varepsilon}
$$

where $\sigma$ is flow stress and $\dot{\varepsilon}$ is strain rate.

\section{Results}

\subsection{Phase Analysis}

Figure 1 shows the polythermal section of the Al-Mg-Si-Cu-Ni equilibrium phase diagram for the Ni concentration of below $5 \mathrm{wt} . \%$ calculated in a ThermoCalc (ThermoCalcdatabase TTA15, Thermo-Calc Software AB, Stockholm, Sweden). The studied alloys are marked in the diagram by the blue vertical lines. The following phases were sequentially 
solidified for the alloys studied in the equilibrium state: the aluminum-based solid solution (Al), the $\mathrm{Al}_{3} \mathrm{Ni}$ and $\mathrm{Mg}_{2} \mathrm{Si}$ phases.

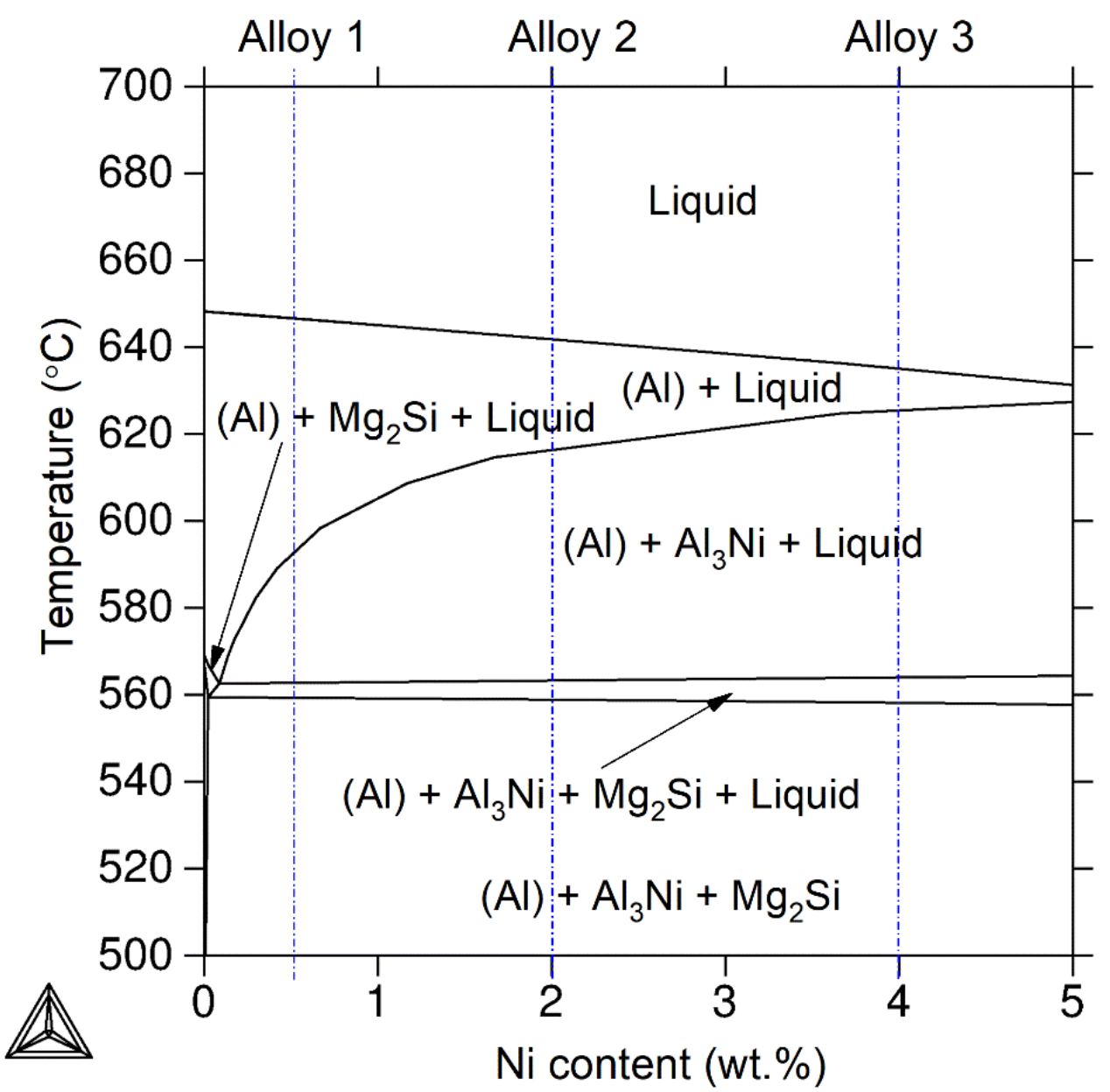

Figure 1. The polythermal section of the equilibrium $\mathrm{Al}-1.2 \% \mathrm{Mg}-0.7 \% \mathrm{Si}-1.0 \% \mathrm{Cu}-\mathrm{var} . \% \mathrm{Ni}$ phase diagram; blue vertical lines show the studied alloys compositions.

\subsection{XRD Analysis}

The XRD analysis was performed to determine the phase composition of Alloys 1 and 3 (Figure 2). The diffractions peaks corresponding to the (Al), $\mathrm{Al}_{3} \mathrm{Ni}, \mathrm{Al}_{2} \mathrm{Cu}$, and $\mathrm{Mg}_{2} \mathrm{Si}$ phases were detected in as-cast state. The $(\mathrm{Al}), \mathrm{Al}_{3} \mathrm{Ni}$, and $\mathrm{Mg}_{2} \mathrm{Si}$ phases were found in as-annealed state. 


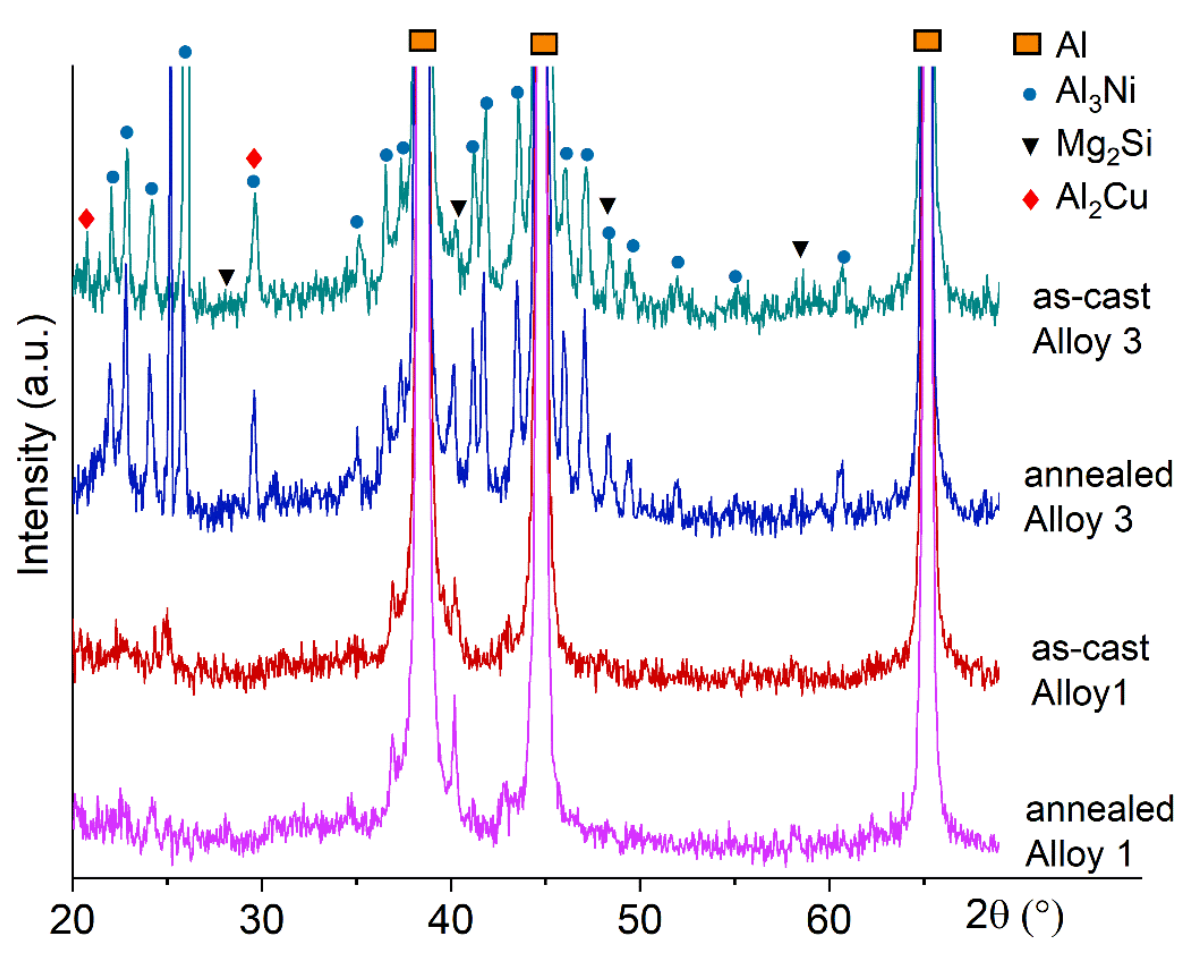

Figure 2. XRD spectrums for the alloys 1 (Al-1.2Mg-0.7Si-1.0Cu-0.5Ni) and 3 (Al-1.2Mg-0.7Si-1.0Cu$4 \mathrm{Ni}$ ) in as-cast and annealed states.

\subsection{SEM Analysis}

Figure 3 shows the BSE images for the studied alloys in the as-cast state. The dominant microstructural feature was the dendrites of the Al-based solid solution. The two types of crystallization-origin phases surrounded the dendrite cells of Al solid solution in the studied alloys; predominantly, the Ni-rich bright phase and the dark Mg- and Si-bearing phase $\left(\mathrm{Mg}_{2} \mathrm{Si}\right)$. The volume fraction of Ni-bearing phase expectedly increased with increasing $\mathrm{Ni}$ content. The colonies of fine lamellar eutectic were observed in alloys 2 and 3 (Figure $3 b, c$ ), whereas the bright phase formed the planes on the periphery of dendrite cells in the alloy 1 with low $\mathrm{Ni}$ content (Figure 3a). The volume fraction of the Ni-rich particles was $2.8 \pm 0.4 \%, 4.8 \pm 0.3 \%$, and $8.2 \pm 0.4 \%$ for the alloys 1,2 , and 3 , respectively. The $\mathrm{Mg}_{2} \mathrm{Si}$ phase appeared predominantly on the periphery of dendrite cells and its volume fraction of $1.2 \pm 0.3 \%$ was similar for the studied alloys. An incomplete superposition of Mg-rich and Si-rich zones in the EDS-maps suggested the presence of a small fraction of ( $\mathrm{Si}$ )-phase in as-cast state. The EDS analysis demonstrated the $\mathrm{Cu}$ segregations on the periphery of the dendrite cells. The Sc and Zr-bearing phases of solidification origin were unobserved and the EDS maps for Sc and $\mathrm{Zr}$ exhibited uniform elemental distribution for the alloys.

SEM micrographs for as-homogenized samples are presented for the alloys 1 and 2 in Figure 4 and for the alloy 3 in Figure 5. The first annealing step at $350{ }^{\circ} \mathrm{C}, 8 \mathrm{~h}$, did not initiate the significant changes in the as-cast microstructure for the studied alloys (Figure $5 \mathrm{a}-\mathrm{f}$ ). The $\mathrm{Al}_{3} \mathrm{Ni}$ phase retained lamellar morphology, and a partial fragmentation of $\mathrm{Mg}$ - and Si-bearing phase was observed (Figure 5f). The chemical composition of the phases was studied in detail after the second step of homogenization at $480^{\circ} \mathrm{C}$. According to the SEM-EDS data, the bright Ni-bearing phase contained $\mathrm{Cu}$ (Figure $4 \mathrm{c}$ ). 


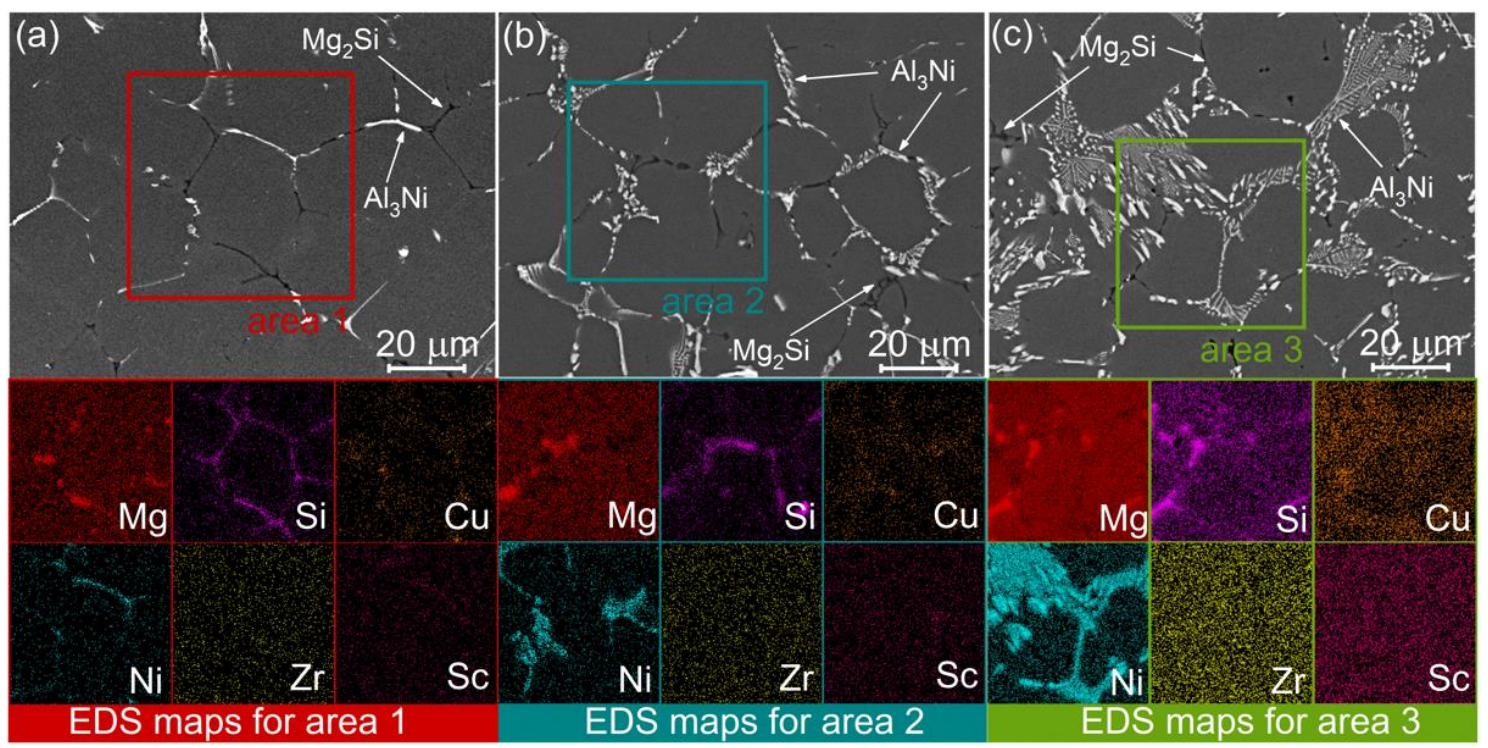

Figure 3. BSE images corresponding to SEM-EDS maps for the (a) alloy 1 (Al-1.2Mg-0.7Si-1.0Cu-0.5Ni), (b) alloy 2 (Al$1.2 \mathrm{Mg}-0.7 \mathrm{Si}-1.0 \mathrm{Cu}-2 \mathrm{Ni})$, and (c) the alloy $3(\mathrm{Al}-1.2 \mathrm{Mg}-0.7 \mathrm{Si}-1.0 \mathrm{Cu}-4 \mathrm{Ni})$ in as-cast state.
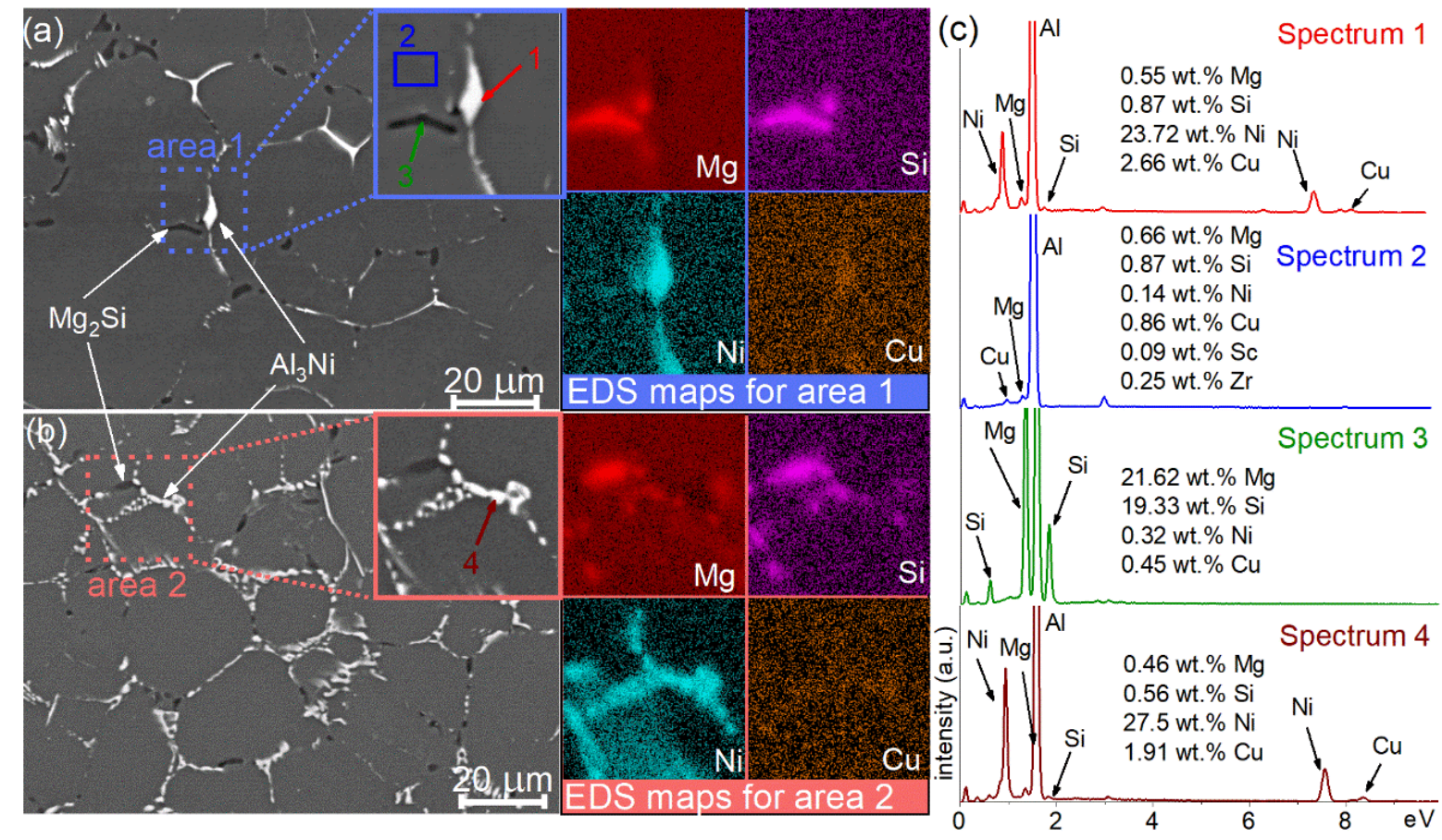

Figure 4. SEM images for the (a) alloy 1 (Al-1.2Mg-0.7Si-1.0Cu-0.5Ni) and (b) alloy 2 (Al-1.2Mg-0.7Si-1.0Cu-2Ni) after the two-step homogenization and corresponded to EDS elemental distribution maps captured from the area 1 in (a) and area 2 in (b); (c) the EDS spectrums corresponded to the area marked-up in insert in $(\mathbf{a}, \mathbf{b})$. 

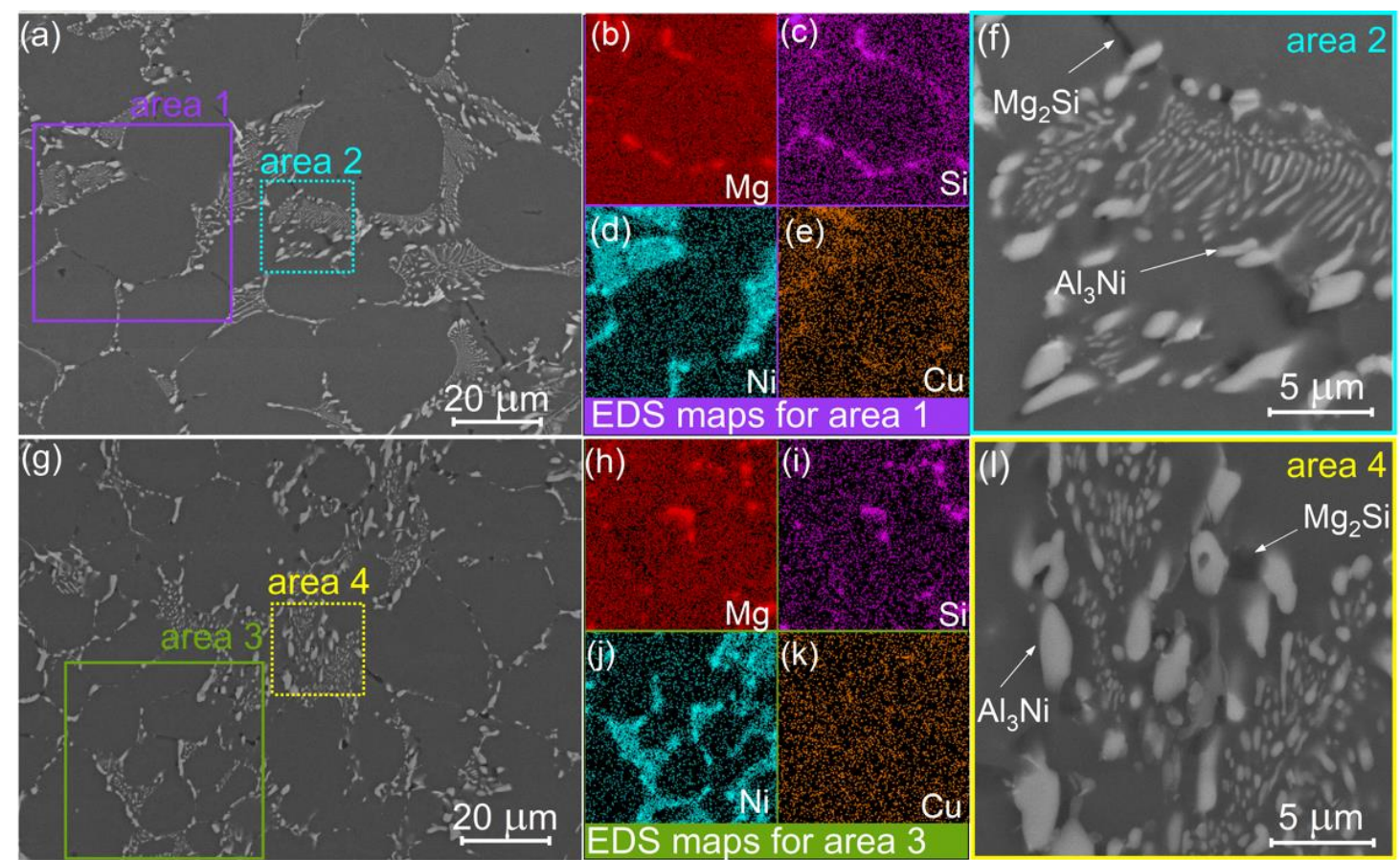

Figure 5. SEM images for the alloy $3(\mathrm{Al}-1.2 \mathrm{Mg}-0.7 \mathrm{Si}-1.0 \mathrm{Cu}-4 \mathrm{Ni})$ after $(\mathbf{a}-\mathbf{f})$ one step homogenization at $350{ }^{\circ} \mathrm{C}, 8 \mathrm{~h}$ and $(\mathrm{g}-\mathbf{l})$ two-step with the first step at $350{ }^{\circ} \mathrm{C}, 8 \mathrm{~h}$ and second step at $480^{\circ} \mathrm{C}, 3 \mathrm{~h} ;(\mathbf{b}-\mathbf{e})$ and $(\mathbf{h}-\mathbf{k})$ are the EDS maps captured from the are marked up with red square in (a) and green square in (g), respectively; (f) and (1) are the magnified areas marked up with blue square in (a) and yellow square in (g), respectively.

The EDS analysis revealed that the bright phase contained $23.7 \mathrm{wt} . \% \mathrm{Ni}, 2.7 \mathrm{wt} . \% \mathrm{Cu}$ for the alloy 1 (Figure 4 spectrum 1), and $7.5 \mathrm{wt} . \% \mathrm{Ni}, 1.9 \mathrm{wt} . \% \mathrm{Cu}$ for the alloy 2 (Figure 4 spectrum 4). The dark phase contained $21.6 \mathrm{wt} . \% \mathrm{Mg}$ and $19.3 \mathrm{wt} . \% \mathrm{Si}$ (Figure 4 spectrum 3 ), whereas the total concentration of the other elements was less than $1 \mathrm{wt} . \%$. The analysis of $\mathrm{Al}$ solid solution revealed $0.7 \% \mathrm{Mg}, 0.9 \% \mathrm{Si}$, and $0.9 \% \mathrm{Cu}$ (Figure 4 spectrum 2). For the alloy 3, the $\mathrm{Cu}$-distribution became more homogeneous after high-temperature annealing. However, a slight increase of the $\mathrm{Cu}$ signal was noticed near the Ni-rich zones.

The second step of homogenization annealing resulted in the fragmentation and spheroidization of the $\mathrm{Mg}_{2} \mathrm{Si}$ phase for the studied alloys (Figures 4 and $5 \mathrm{~g}, 1$ ). The dominant fraction of the Ni-rich phase exhibited non-fragmentized lamellae for the alloy 1 with $0.5 \%$ $\mathrm{Ni}$ after the second step of homogenization (Figure 4a). The partial fragmentation of Nibearing particles was observed for the alloy 2 with $2 \mathrm{wt} . \% \mathrm{Ni}$ (Figure $4 \mathrm{~b}$ ). The fragmentation of the Ni-bearing phase was significant for the alloy 3 with $4 \%$ Ni.

Figure 6 shows the SEM micrographs of the alloys studied after a simple thermomechanical treatment and post-deformation annealing at $480^{\circ} \mathrm{C}$ for $20 \mathrm{~min}$. A near-homogeneous distribution of the solidification origin particles was observed in the alloys studied after sheet processing. 

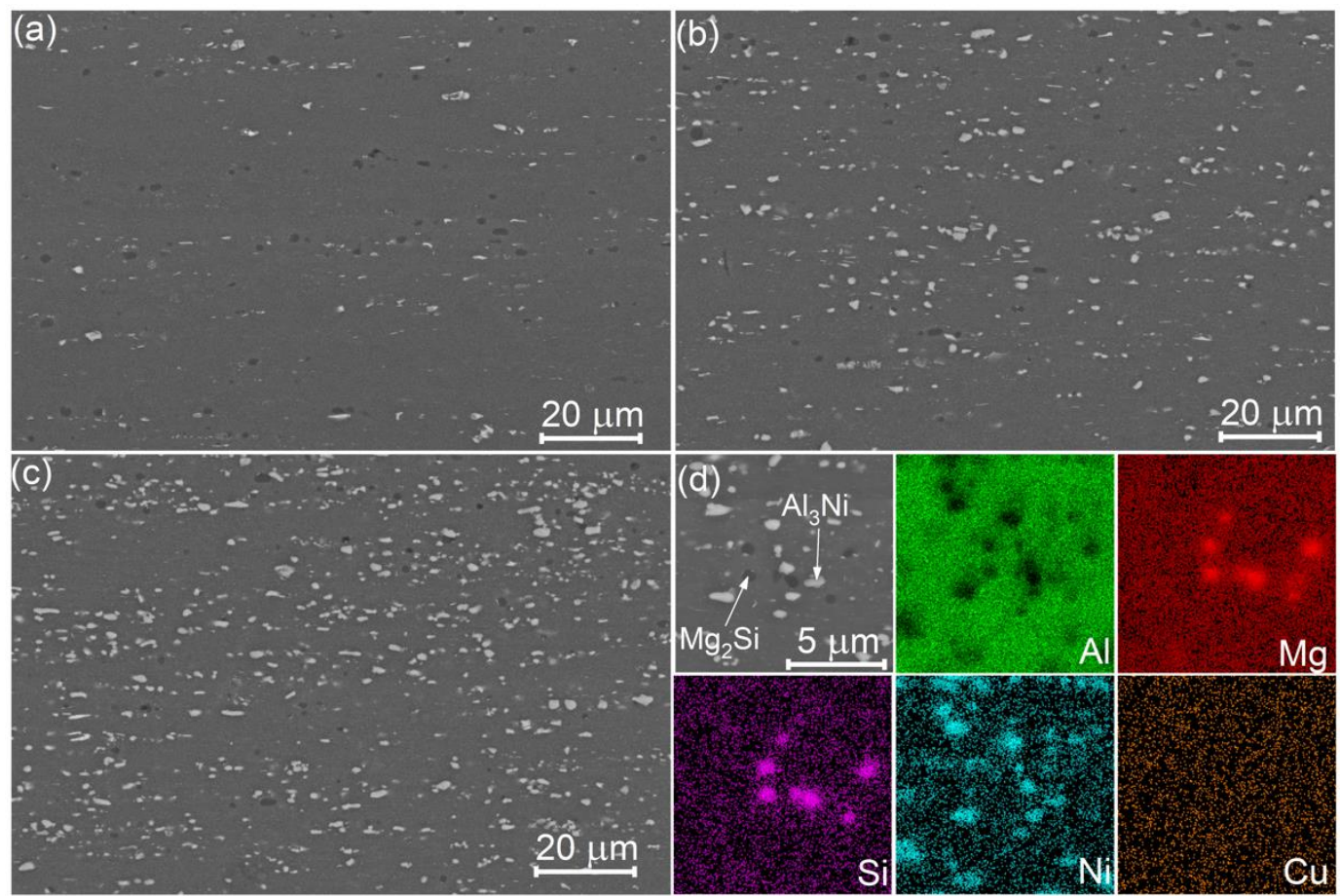

Figure 6. SEM images of cold rolled sheets after final $20 \mathrm{~min}$ annealing at $480{ }^{\circ} \mathrm{C}$ for the (a) alloy 1 (Al-1.2Mg-0.7Si1.0Cu-0.5Ni), (b) alloy $2(\mathrm{Al}-1.2 \mathrm{Mg}-0.7 \mathrm{Si}-1.0 \mathrm{Cu}-2 \mathrm{Ni})$, and (c,d) alloy $3(\mathrm{Al}-1.2 \mathrm{Mg}-0.7 \mathrm{Si}-1.0 \mathrm{Cu}-4 \mathrm{Ni})$ with corresponded SEM-EDS maps.

The particles size distribution histograms (Figure 7) exhibited gamma distribution for both types of particles. The mean sizes of bright Ni-bearing particles were $1.7 \pm 0.1$, $1.6 \pm 0.1$, and $1.4 \pm 0.2$, and the mean sizes of $\mathrm{Mg}_{2}$ Si particles were $1.4 \pm 0.1,1.4 \pm 0.1$, and $1.6 \pm 0.1$, for the alloys 1,2 , and 3 , respectively.
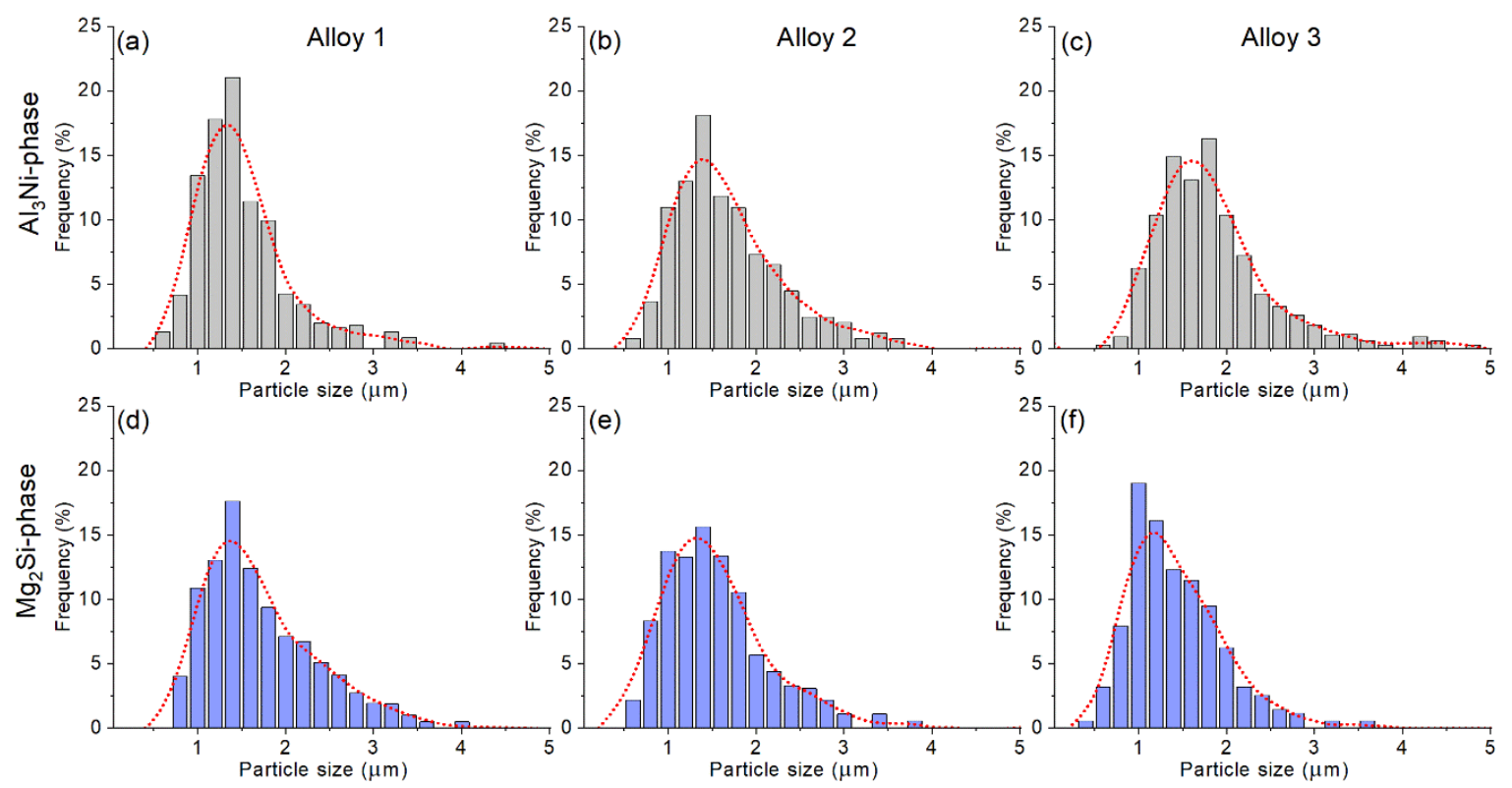

Figure 7. The particle size distribution histograms of the $(\mathbf{a}-\mathbf{c}) \mathrm{Al}_{3} \mathrm{Ni}$ and $(\mathbf{d}-\mathbf{f}) \mathrm{Mg}_{2} \mathrm{Si}$ phases for the thermomechanical treated (a,d) alloy 1 (Al-1.2Mg-0.7Si-1.0Cu-0.5Ni), (b,e) alloy 2 (Al-1.2Mg-0.7Si-1.0Cu-2Ni), and (c,f) alloy 3 (Al-1.2Mg-0.7Si$1.0 \mathrm{Cu}-4 \mathrm{Ni})$. 


\subsection{Dispersoids Parameters}

The TEM analysis of the alloy 3 after a two-step annealing revealed a high-density of uniformly distributed nanoscale dispersoids with a mean size of $10 \pm 1 \mathrm{~nm}$ (Figure 8a,b). The corresponding selected area electron diffraction (SAED) in [111 $]_{1}$ zone axis exhibited typical for the $\mathrm{L} 1_{2}$-phase ordered superlattice reflections (Figure 8c). The [111] zone axis of $\mathrm{L1}_{2}$ phase is parallel to [111] zone axis of Al.
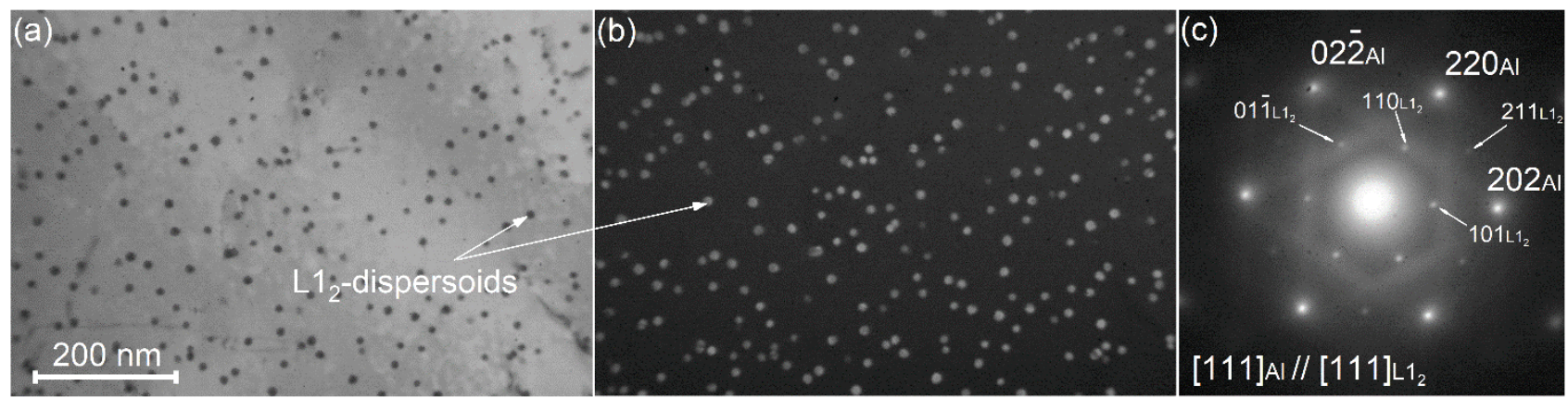

Figure 8. TEM images for the alloy 3 (Al-1.2Mg-0.7Si-1.0Cu-3Ni) after two-step annealing; (a) bright field; (b) dark field; (c) corresponded SAED.

\subsection{Grain Structure for the Thermomechanically Treated Samples}

High density of $\mathrm{L}_{2}$ precipitates provided a partially non-recrystallized band-like grain structure after post deformation annealing in a temperature range of $440-500{ }^{\circ} \mathrm{C}$ for $20 \mathrm{~min}$ (Figure 9). The fraction of the recrystallized grains decreased with increasing volume fraction of $\mathrm{Al}_{3} \mathrm{Ni}$ particles. The mean thickness of non-recrystallized grains decreased with increasing Ni content and were $8.4 \pm 1.3,6.8 \pm 0.5,5.5 \pm 0.5$ and $4.0 \pm 0.3 \mu \mathrm{m}$ for $\mathrm{Ni}$-free reference alloy, alloy 1 , alloy 2 , and alloy 3 , respectively (Figure 9a-d).
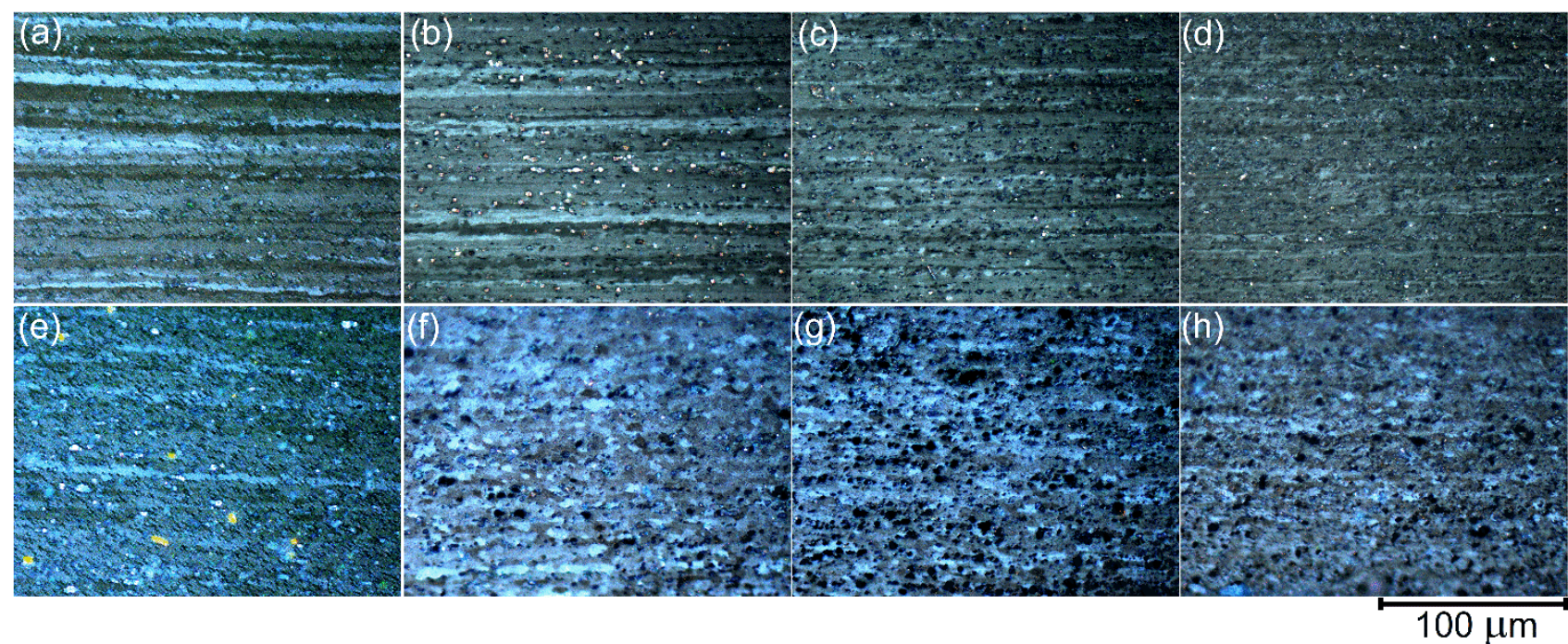

Figure 9. The grain structure for the (a,e) reference Ni-free alloy, $(\mathbf{b}, \mathbf{f})$ alloy 1 (Al-1.2Mg-0.7Si-1.0Cu- $0.5 \mathrm{Ni}),(\mathbf{c}, \mathbf{g})$ alloy 2 (Al-1.2Mg-0.7Si-1.0Cu-2Ni), and (d,h) alloy $3(\mathrm{Al}-1.2 \mathrm{Mg}-0.7 \mathrm{Si}-1.0 \mathrm{Cu}-4 \mathrm{Ni})$ after the thermomechanical treatment and final annealing at (a-d) $500{ }^{\circ} \mathrm{C}$ for $20 \mathrm{~min}$ and (e-h) $300 \%$ of strain at $460{ }^{\circ} \mathrm{C}$ and constant strain rate of $5 \times 10^{-3} \mathrm{~s}^{-1}$.

\subsection{The Tensile Test at Elevated Temperatures}

The superplastic deformation behavior was analyzed in a temperature range of $440-500{ }^{\circ} \mathrm{C}$ and a constant strain rate range of $2 \times 10^{-3}-5 \times 10^{-2} \mathrm{~s}^{-1}$ (Figure 10). The flow stress decreased with increasing temperature and decreasing strain rate. In the studied 
temperature limits, the maximum stress was observed at the maximum studied strain rate of $5 \times 10^{-2} \mathrm{~s}^{-1}$. In a temperature range of $440-500{ }^{\circ} \mathrm{C}$, the maximum stress values varied in a range of 27-48 MPa, 26-45 MPa, and 25-40 MPa for alloys with $0.5,2$, and $4 \mathrm{wt} . \% \mathrm{Ni}$, respectively. The minimum stress value was achieved at $2 \times 10^{-3} \mathrm{~s}^{-1}$. In a temperature range of $440-500{ }^{\circ} \mathrm{C}$, the minimum stress values varied in a range of $15-18 \mathrm{MPa}, 12-16 \mathrm{MPa}$, and 10-15 MPa for $0.5,2$, and $4 \mathrm{wt} . \% \mathrm{Ni}$, respectively. An increase in Ni content led to a decrease in the flow stress for the studied temperatures.
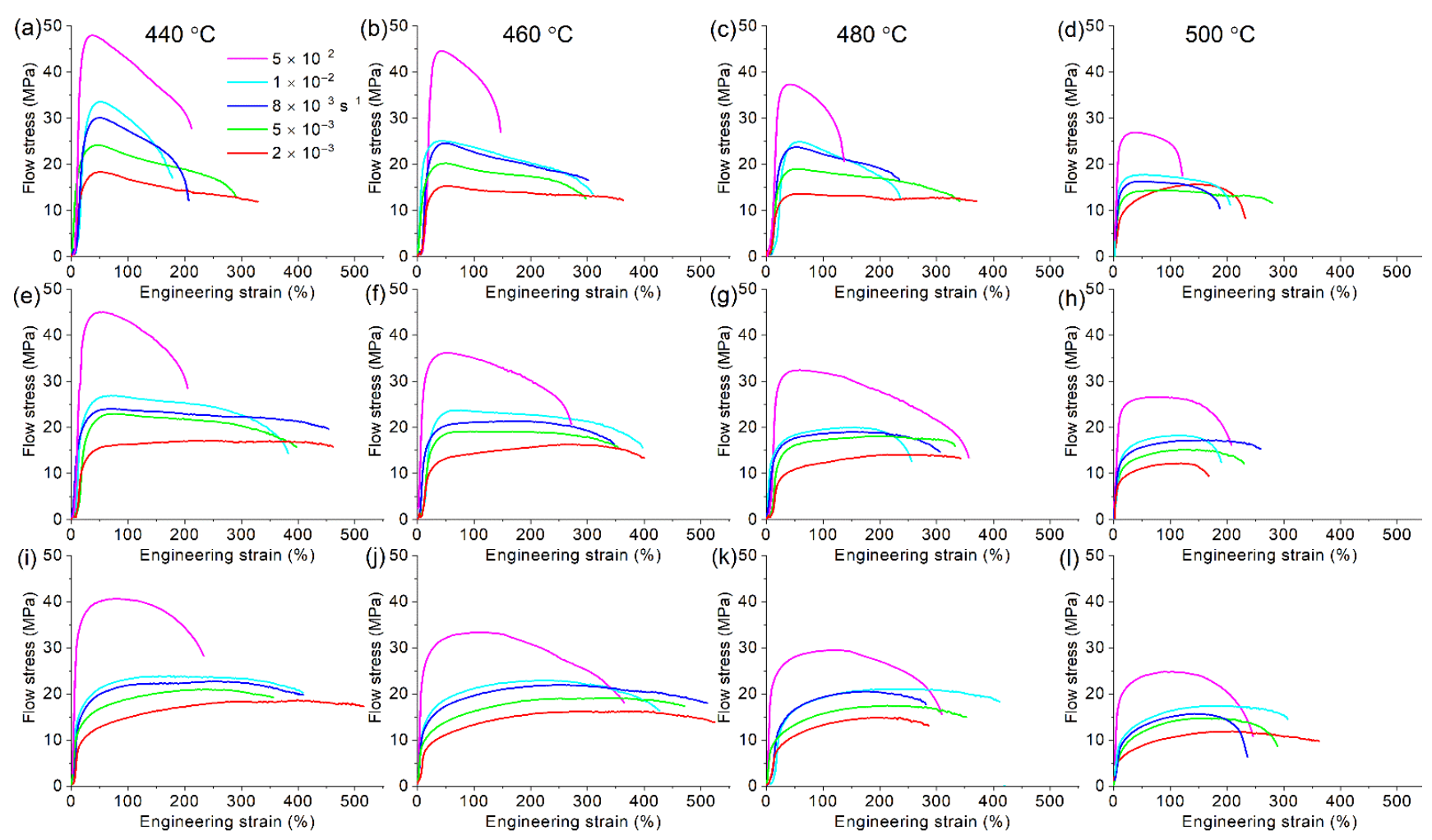

Figure 10. The flow stress-strain dependences for the (a-d) alloy 1 (Al-1.2Mg-0.7Si-1.0Cu-0.5Ni), (e-h) alloy 2 (Al-1.2Mg$0.7 \mathrm{Si}-1.0 \mathrm{Cu}-2 \mathrm{Ni})$, and (i-1) alloy $3(\mathrm{Al}-1.2 \mathrm{Mg}-0.7 \mathrm{Si}-1.0 \mathrm{Cu}-4 \mathrm{Ni})$ in a strain rate range of $2 \times 10^{-3} \mathrm{~s}^{-1}-5 \times 10^{-2} \mathrm{~s}^{-1}$ and temperatures of $(\mathbf{a}, \mathbf{e}, \mathbf{i}) 440^{\circ} \mathrm{C},(\mathbf{b}, \mathbf{f}, \mathbf{j}) 460^{\circ} \mathrm{C},(\mathbf{c}, \mathbf{g}, \mathbf{k}) 480^{\circ} \mathrm{C}$, and $(\mathbf{d}, \mathbf{h}, \mathbf{l}) 500{ }^{\circ} \mathrm{C}$.

At the studied deformation conditions, the elongation-to-failure was varied from 130 to $520 \%$. The alloy 1 with $0.5 \% \mathrm{Ni}$ exhibited superplasticity with elongation-to-failure of $300-370 \%$ at $440-480{ }^{\circ} \mathrm{C}$ and strain rates of $(2-8) \times 10^{-3} \mathrm{~s}^{-1}$ (Figure $10 \mathrm{a}-\mathrm{c}$ ). At higher strain rates, the elongation did not exceed $200 \%$. The alloys with 2 and $4 \% \mathrm{Ni}$ exhibited a similar deformation behavior. For the alloy 2 with $2 \% \mathrm{Ni}$, the maximum elongation-tofailure of $370-400 \%$ was achieved at temperatures of $440-460{ }^{\circ} \mathrm{C}$ in a strain rate range of $2 \times 10^{-3} \mathrm{~s}^{-1}-1 \times 10^{-2} \mathrm{~s}^{-1}$ (Figure 10e,f). The maximum elongation of $520 \%$ was achieved at $460{ }^{\circ} \mathrm{C}$ and (2-8) $\times 10^{-3} \mathrm{~s}^{-1}$ for the alloy 3 with $4 \% \mathrm{Ni}$ (Figure 10j). At the higher strain rates of $(1-5) \times 10^{-2} \mathrm{~s}^{-1}$, the alloy exhibited elongation of $350-420 \%$. For the decreased temperature of $440^{\circ} \mathrm{C}$, at high strain rates of $5 \times 10^{-2} \mathrm{~s}^{-1}$, the elongation was below $230 \%$, whereas a strain rate of $2 \times 10^{-3} \mathrm{~s}^{-1}$ provided the elongation of $520 \%$ (Figure $10 \mathrm{i}$ ). The temperature increase to $480-500{ }^{\circ} \mathrm{C}$ resulted in a decrease in elongation in both alloys 2 and 3 (Figure $10 \mathrm{~g}, \mathrm{~h}, \mathrm{k}, \mathrm{l}$ ). The elongation of $360 \%$ at $500{ }^{\circ} \mathrm{C}$ was achieved for the alloy 3 with $4 \% \mathrm{Ni}$ at a low strain rate of $2 \times 10^{-3} \mathrm{~s}^{-1}$ (Figure 101).

The superplastic behavior of the Ni-free reference alloy was analyzed in similar testing conditions. The alloy exhibited elongation-to-failure of $250-300 \%$ in a strain rate range of $2 \times 10^{-3}-1 \times 10^{-2} \mathrm{~s}^{-1}$ and a temperature range of $440-500{ }^{\circ} \mathrm{C}$ (Figure 11), and nonsuperplastic flow accompanied by necking with $120 \%$ of elongation was observed at a constant strain rate of $5 \times 10^{-2} \mathrm{~s}^{-1}$. 

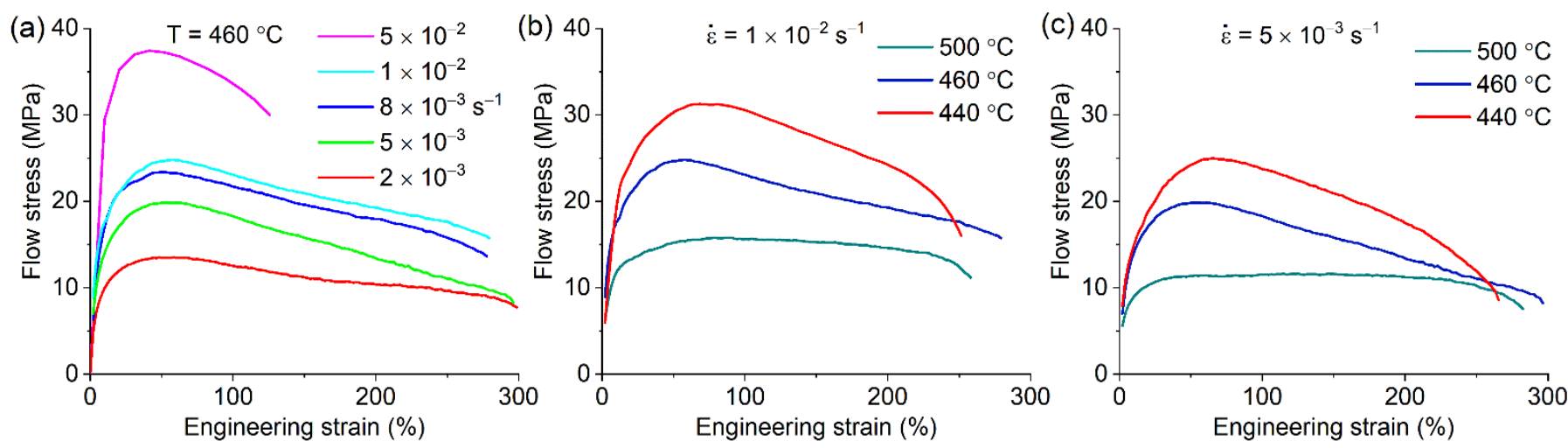

Figure 11. The flow stress-strain dependences for the reference Ni-free alloy at (a) $460{ }^{\circ} \mathrm{C}$ in a strain rate range of $1 \times 10^{-2}-5 \times 10^{-3} \mathrm{~s}^{-1}$ and at constant strain rates of (b) $1 \times 10^{-2} \mathrm{~s}^{-1}$ and (c) $5 \times 10^{-3} \mathrm{~s}^{-1}$ for 440,460 and $500{ }^{\circ} \mathrm{C}$.

The strain rate sensitivity coefficient $m$ was determined at $460{ }^{\circ} \mathrm{C}$ for $50 \%$ strains (Figure 12a). The $m$-values were above 0.3 in a strain rate range of (2-5) $\times 10^{-3} \mathrm{~s}^{-1}$ for the alloy with $0.5 \% \mathrm{Ni}$. The $m$-values of $0.35-0.45$ were observed in the alloys with $2 \%$ and $4 \%$ $\mathrm{Ni}$ in a strain rate range of $5 \times 10^{-3}-5 \times 10^{-2} \mathrm{~s}^{-1}$. For the Ni-free alloy, the coefficient $m$ was above 0.3 in a strain rate range of $(2-8) \times 10^{-3} \mathrm{~s}^{-1}$ and below 0.3 at higher strain rates. An $m$ coefficient value higher than 0.35 resulted in increased elongation to failure at $460{ }^{\circ} \mathrm{C}$ (Figure 12b).

(a)

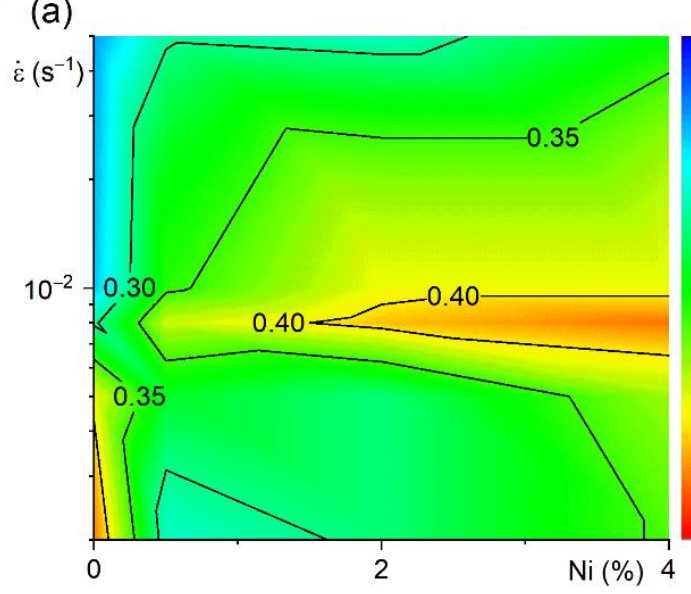

(b)

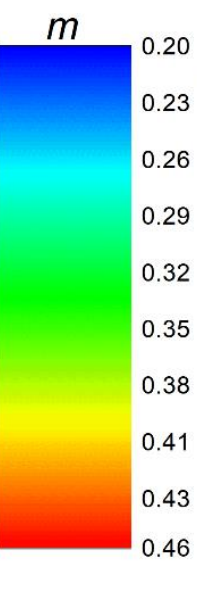

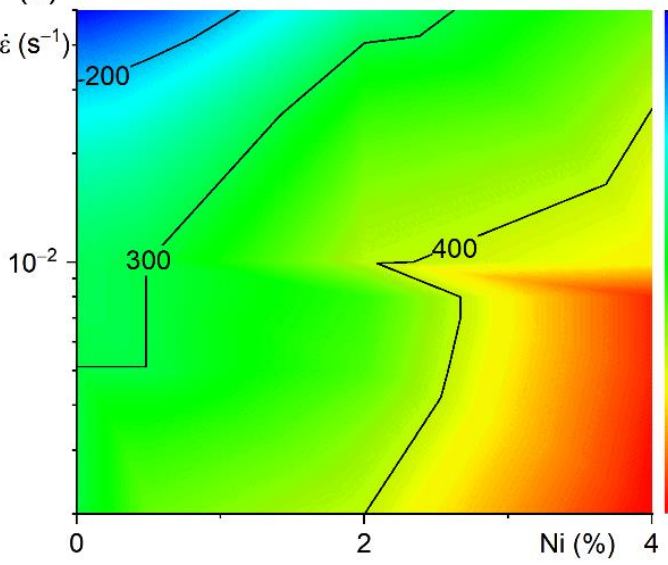

El (\%)

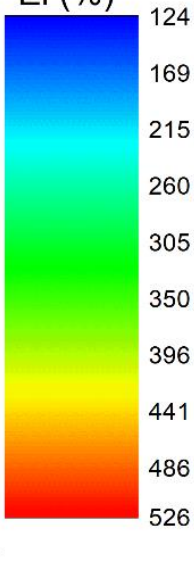

Figure 12. The dependences of (a) strain rate sensitivity $m$-coefficient and (b) elongation to failure vs. Ni content (x-axis) and strain rate (y-axis) at $460^{\circ} \mathrm{C}$.

The dynamic recrystallization occurred during the superplastic deformation and

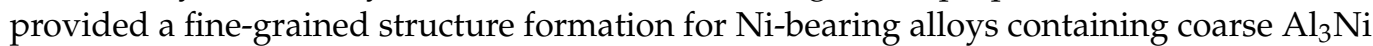
particles. After deformation of $300 \%$ at $460{ }^{\circ} \mathrm{C}$ with a constant strain rate of $5 \times 10^{-3} \mathrm{~s}^{-1}$, a mean grain size was $9.9 \pm 0.6,7.2 \pm 0.6$, and $5.9 \pm 0.6 \mu \mathrm{m}$ for the alloys 1,2 , and 3 , respectively (Figure $9 \mathrm{f}-\mathrm{h}$ ). The reference alloy that contained a low fraction of coarse particles demonstrated partially non-recrystallized grain structure, even after the failure at $300 \%$ and a mean grain size in the recrystallized areas was $16 \pm 1 \mu \mathrm{m}$ (Figure 9e).

\section{Discussion}

The thermodynamic calculation, XRD analysis and SEM studies confirmed the presence of $\mathrm{Mg}_{2} \mathrm{Si}$ phase, and the $\mathrm{Al}_{3} \mathrm{Ni}$ phase of crystallization origin. For an as-cast state, a small amount of non-equilibrium (Si) phase also was found by SEM-EDS. The (Si) phase was dissolved during homogenization annealing. The bright particles of crystallization origin belonged to $\mathrm{Al}_{3} \mathrm{Ni}$ phase were found in as-cast state. The non-equilibrium $\mathrm{Al}_{2} \mathrm{Cu}$ 
phase observed in as-cast state was dissolved during homogenization. Meanwhile, the SEM-EDS analysis for the bright phase after homogenization revealed an increased concentration of $\mathrm{Cu}$, comparing it to that of for the aluminum-based solid solution (Al). This can be a consequence of partial substitution of $\mathrm{Ni}$ atoms by $\mathrm{Cu}$ atoms in $\mathrm{Al}_{3} \mathrm{Ni}$ phase or the result of $\mathrm{Al}_{2} \mathrm{Cu}$ phase that was incompletely dissolved during the homogenization. It can also be suggested that $\mathrm{Cu}$-rich $\mathrm{Al}_{7} \mathrm{Cu}_{4} \mathrm{Ni}$-phase can be formed in the alloy 1 with low $\mathrm{Ni} / \mathrm{Cu}$ ratio [67].

The $\mathrm{Mg}_{2} \mathrm{Si}$ phase was fragmentized and spheroidized during homogenization of the studied alloys. The microstructural studies of the as-annealed samples revealed differences in the evolution of the $\mathrm{Al}_{3} \mathrm{Ni}$ lamellae. The fragmentation was observed for the alloys 2 and 3 with increased $\mathrm{Ni}$ content, whereas $\mathrm{Al}_{3} \mathrm{Ni}$ phase retained its elongated shape in the alloy 1 with $0.5 \% \mathrm{Ni}$. It can be suggested that $\mathrm{Cu}$ atoms were dissolved in the $\mathrm{Al}_{3} \mathrm{Ni}$ phase and increased its thermal stability and inhibited fragmentation. The increasing of $\mathrm{Ni}$ content results in a higher fraction of $\mathrm{Al}_{3} \mathrm{Ni}$ eutectic phase and, therefore, the effect of $\mathrm{Cu}$ becomes increasingly insignificant. After the thermomechanical treatment, a near-uniform distribution of the $\mathrm{Al}_{3} \mathrm{Ni}$ and $\mathrm{Mg}_{2} \mathrm{Si}$ particles with a mean size of 1.4-1.6 $\mu \mathrm{m}$ was observed.

Nickel has an extremely low solubility in aluminum at conventional solidification conditions [68], and the dissolution of $\mathrm{Ni}$ in the $\mathrm{Sc}$ and $\mathrm{Zr}$ bearing precipitates was not observed by atomic probe tomography $[69,70]$, therefore, $\mathrm{Ni}$ cannot significantly influence the precipitation kinetics and parameters of dispersoids. It has been suggested that the precipitation behavior of the alloys with different $\mathrm{Ni}$ content was similar. It should be mentioned that the applied homogenization annealing provided $\mathrm{L}_{2}-\mathrm{Al}_{3}(\mathrm{Sc}, \mathrm{Zr})$ dispersoids with a size of about $10 \mathrm{~nm}$ that is similar to the size of precipitates formed at low temperature annealing [43]. We also suggest that $\mathrm{Si}$ atoms partially substitute $\mathrm{Al}$ in $\mathrm{L}_{2}$ phase providing a more complex dispersoids of $(\mathrm{Al}, \mathrm{Si})_{3}(\mathrm{Sc}, \mathrm{Zr})$ phase as it was demonstrated in Refs. [71,72]. The zone axis [111] of the dispersoids agglomeration was parallel to the corresponding zone axis of the $\mathrm{Al}$ matrix that suggested coherency/semi-coherency for the dispersoids and Al matrix. The alloys exhibited partially unrecrystallized grain structure before the start of the superplastic deformation up to a temperature of $500{ }^{\circ} \mathrm{C}$. This emphasizes a strong dislocation pinning effect, due to the $\mathrm{L}_{2}$ dispersoids, which inhibited recrystallization during heating to the superplastic deformation temperature.

The role of the secondary particles on the superplastic behavior is follows. The wellknown superplastic deformation mechanisms are grain boundary sliding, dislocation and diffusional creep [10,73-78]. Due to the diffusion-controlled nature of these mechanisms, the superplasticity is usually observed at elevated temperatures and low strain rates. Grain refinement simplifies grain boundary sliding and its accommodation by dislocation and diffusional creep, therefore, superplastic behavior is observed at higher strain rates and lower temperatures [20,79]. The bimodal particles size distribution with $\mathrm{Al}_{3} \mathrm{Ni}$ and $\mathrm{Mg}_{2} \mathrm{Si}$ particles of about $1-2 \mu \mathrm{m}$ in size, and $\mathrm{L}_{2}$ precipitates with size of $10 \mathrm{~nm}$ contributed significantly to the grain refinement and provided high strain rate superplasticity for the studied alloys. The $\mathrm{Al}_{3} \mathrm{Ni}$ phase particles accumulate dislocations near interphase boundaries and provide the pronounced PSN effect during the superplastic flow $[20,42,58]$. Due to $\mathrm{PSN}$ mechanism, $\mathrm{Al}_{3} \mathrm{Ni}$ particles increased the dynamic recrystallization rate during the deformation and provided grain refinement. The reference alloy without $\mathrm{Ni}$ and $\mathrm{Al}_{3} \mathrm{Ni}$ particles demonstrated weak superplasticity at higher strain rates due to suppressed dynamic recrystallization. In addition, $\mathrm{Al}_{3} \mathrm{Ni}$ particles form interphase boundaries with aluminum matrix. An increased fraction of the interphase boundaries as well as grain boundaries can accelerate the alloy diffusivity and support the acting of diffusion-controlled superplastic deformation mechanisms. As a result, an increase in $\mathrm{Al}_{3} \mathrm{Ni}$ phase fraction increased the elongation-to-failure and decreased the flow stress values. The fine $\mathrm{L1}_{2}$ precipitates provided a strong Zener pinning effect, inhibiting dynamic grain growth and providing a stable flow during superplastic deformation. 


\section{Conclusions}

The microstructure and the superplastic deformation behavior were studied for the Al-1.2Mg-0.7Si-1Cu-xNi-0.1Sc-0.2Zr alloys, where $\mathrm{x}=0,0.5,2$, and $4 \mathrm{wt} . \%$. The sheets were processed by a simple thermomechanical treatment included homogenization annealing, hot and cold rolling. The main conclusions are drawn as follows:

1. The bimodal particles size distribution with the coarse crystallization-origin particles of the $\mathrm{Mg}_{2} \mathrm{Si}$ and $\mathrm{Al}_{3} \mathrm{Ni}$ phases with 1.4-1.6 $\mu \mathrm{m}$ mean size and $\mathrm{L1}_{2}$-structured dispersoids of the $\mathrm{Al}_{3}(\mathrm{Sc}, \mathrm{Zr})$ phase with a mean size of $11 \pm 1 \mathrm{~nm}$ were formed in the studied alloys. The volume fraction of the $\mathrm{Mg}_{2} \mathrm{Si}$ phase was $1.2 \%$ and the volume fraction of the $\mathrm{Al}_{3} \mathrm{Ni}$ phase increased from 2.8 to $8 \%$, with increasing $\mathrm{Ni}$-content from 0.5 to $4 \%$.

2. The alloys studied exhibited superplasticity in a strain rate range of $2 \times 10^{-3}-5 \times 10^{-2} \mathrm{~s}^{-1}$ and a temperature range of $440-500{ }^{\circ} \mathrm{C}$. Due to a particle stimulated nucleation effect, an increase in $\mathrm{Al}_{3} \mathrm{Ni}$ phase fraction provided grain refinement during the superplastic deformation, increased the value of elongation-to-failure and decreased flow stress values. An elongation increased from $250-300 \%$ for the alloys, with $0-0.5 \% \mathrm{Ni}$ to $400-500 \%$ for the alloy with $4 \% \mathrm{Ni}$, which exhibited superplasticity even at a strain rate of $5 \times 10^{-2} \mathrm{~s}^{-1}$.

Author Contributions: Conceptualization, A.M. (Andrey Mochugovskiy) and A.M. (Anastasia Mikhaylovskaya); methodology, M.E.G. and A.K.; software, A.K.; validation, M.E.G. and O.Y.; formal analysis, A.K.; investigation, A.M. (Andrey Mochugovskiy), M.E.G. and A.M. (Anastasia Mikhaylovskaya); data curation, O.Y.; writing —original draft preparation, A.M. (Andrey Mochugovskiy) and A.M. (Anastasia Mikhaylovskaya); writing — review and editing, A.M. (Anastasia Mikhaylovskaya) and M.E.G.; visualization, O.Y.; supervision, A.M. (Anastasia Mikhaylovskaya). All authors have read and agreed to the published version of the manuscript.

Funding: This work was funded by the Russian Science Foundation in a framework of [Grant\#20-79-00269].

Institutional Review Board Statement: Not applicable.

Informed Consent Statement: Not applicable.

Data Availability Statement: The raw and processed data required to reproduce these results are available by contacting the authors.

Conflicts of Interest: The authors declare no conflict of interest.

\section{References}

1. Miller, W.; Zhuang, L.; Bottema, J.; Wittebrood, A.; De Smet, P.; Haszler, A.; Vieregge, A. Recent development in aluminium alloys for the automotive industry. Mater. Sci. Eng. A 2000, 280, 37-49. [CrossRef]

2. Heinz, A.; Haszler, A.; Keidel, C.; Moldenhauer, S.; Benedictus, R.; Miller, W. Recent development in aluminium alloys for aerospace applications. Mater. Sci. Eng. A 2000, 280, 102-107. [CrossRef]

3. Chakrabarti, D.; Laughlin, D.E. Phase relations and precipitation in Al-Mg-Si alloys with Cu additions. Prog. Mater. Sci. 2004, 49, 389-410. [CrossRef]

4. Yang, W.; Wang, M.; Zhang, R.; Zhang, Q.; Sheng, X. The diffraction patterns from $\beta$ " precipitates in 12 orientations in Al-Mg-Si alloy. Scr. Mater. 2010, 62, 705-708. [CrossRef]

5. Dong, X.; Ji, S. Si poisoning and promotion on the microstructure and mechanical properties of Al-Si-Mg cast alloys. J. Mater. Sci. 2018, 53, 7778-7792. [CrossRef]

6. Vissers, R.; van Huis, M.A.; Jansen, J.; Zandbergen, H.W.; Marioara, C.D.; Andersen, S.J. The crystal structure of the $\beta^{\prime}$ phase in Al-Mg-Si alloys. Acta Mater. 2007, 55, 3815-3823. [CrossRef]

7. Miao, W.F.; Laughlin, D.E. Effects of Cu content and preaging on precipitation characteristics in aluminum alloy 6022 . Metall Mater. Trans. A 2000, 31, 361-371. [CrossRef]

8. Chakrabarti, D.J.; Peng, Y.; Laughlin, D.E. Precipitation in Al-Mg-Si Alloys with Cu Additions and the Role of the Q' and Related Phases. Mater. Sci. Forum 2002, 396-402, 857-862. [CrossRef]

9. Staab, T.E.M.; Krause-Rehberg, R.; Hornauer, U.; Zschech, E. Study of artificial aging in AlMgSi (6061) and AlMgSiCu (6013) alloys by Positron Annihilation. J. Mater. Sci. 2006, 41, 1059-1066. [CrossRef]

10. Sotoudeh, K.; Bate, P.S. Diffusion creep and superplasticity in aluminium alloys. Acta Mater. 2010, 58, 1909-1920. [CrossRef] 
11. Mukhopadhyay, P. Alloy Designation, Processing, and Use of AA6XXX Series Aluminium Alloys. ISRN Metall. 2012, $2012,165082$. [CrossRef]

12. Chauhan, K.P.S. Influence of Heat Treatment on the Mechanical Properties of Aluminium Alloys (6xxx Series): A Literature Review. Int. J. Eng. Res. 2017, 6, 386-389. [CrossRef]

13. Chao, D.Y.; Shao, W.Z.; Jiang, J.T.; Zhen, L. Analysis Of Surface Orange Peel Of Automotive Aluminum Alloy Pipe Using Electron Backscatter Diffraction (EBSD). KnE Mater. Sci. 2016, 1, 24-30. [CrossRef]

14. Troeger, L.P.; Starke, E.A. Particle-stimulated nucleation of recrystallization for grain-size control and superplasticity in an Al-Mg-Si-Cu alloy. Mater. Sci. Eng. A 2000, 293, 19-29. [CrossRef]

15. Troeger, L.P.; Starke, E.A. Microstructural and mechanical characterization of a superplastic 6xxx aluminum alloy. Mater. Sci. Eng. A 2000, 277, 102-113. [CrossRef]

16. Wert, J.A.; Paton, N.E.; Hamilton, C.H.; Mahoney, M.W. Grain refinement in 7075 aluminum by thermomechanical processing. Metall. Trans. A 1981, 12, 1267-1276. [CrossRef]

17. Jafarian, H.R.; Mousavi Anijdan, S.H.; Miyamoto, H. Observation of low temperature superplasticity in an ultrafine grained AA6063 alloy. Mater. Sci. Eng. A 2020, 795, 140015. [CrossRef]

18. Bobruk, E.V.; Safargalina, Z.A.; Golubev, O.V.; Baykov, D.; Kazykhanov, V.U. The effect of ultrafine-grained states on superplastic behavior of Al-Mg-Si alloy. Mater. Lett. 2019, 255, 126503. [CrossRef]

19. Hussain, M.; Nageswara Rao, P.; Jayaganthan, R. Development of Ultrafine-Grained Al-Mg-Si Alloy through SPD Processing. Metallogr. Microstruct. Anal. 2015, 4, 219-228. [CrossRef]

20. Wang, X.; Li, Q.; Wu, R.; Zhang, X.; Ma, L. A Review on Superplastic Formation Behavior of Al Alloys. Adv. Mater. Sci. Eng. 2018, 2018, 7606140. [CrossRef]

21. Humphreys, F.J. The nucleation of recrystallization at second phase particles in deformed aluminium. Acta Metall. 1977, 25, 1323-1344. [CrossRef]

22. Gutierrez-Urrutia, I.; Muñoz-Morris, M.A.; Morris, D.G. Contribution of microstructural parameters to strengthening in an ultrafine-grained Al-7\% Si alloy processed by severe deformation. Acta Mater. 2007, 55, 1319-1330. [CrossRef]

23. Kishchik, M.S.; Mikhailovskaya, A.V.; Kotov, A.D.; Drits, A.M.; Portnoy, V.K. Effect of Modes of Heterogenizing Annealing Before Cold Rolling on the Structure and Properties of Sheets from Alloy 1565ch. Met. Sci. Heat Treat. 2019, 61, 228-233. [CrossRef]

24. Kishchik, A.A.; Mikhaylovskaya, A.V.; Kotov, A.D.; Rofman, O.V.; Portnoy, V.K. Al-Mg-Fe-Ni based alloy for high strain rate superplastic forming. Mater. Sci. Eng. A 2018, 718, 190-197. [CrossRef]

25. Mikhaylovskaya, A.V.; Kishchik, A.A.; Kotov, A.D.; Rofman, O.V.; Tabachkova, N.Y. Precipitation behavior and high strain rate superplasticity in a novel fine-grained aluminum based alloy. Mater. Sci. Eng. A 2019, 760, 37-46. [CrossRef]

26. Belov, N.A.; Alabin, A.N.; Eskin, D.G. Improving the properties of cold-rolled Al-6\%Ni sheets by alloying and heat treatment. Scr. Mater. 2004, 50, 89-94. [CrossRef]

27. Mikhaylovskaya, A.V.; Ryazantseva, M.A.; Portnoy, V.K. Effect of eutectic particles on the grain size control and the superplasticity of aluminium alloys. Mater. Sci. Eng. A 2011, 528, 7306-7309. [CrossRef]

28. Akopyan, T.K.; Belov, N.A.; Naumova, E.A.; Letyagin, N.V. New in-situ Al matrix composites based on Al-Ni-La eutectic. Mater. Lett. 2019, 245, 110-113. [CrossRef]

29. Mikhaylovskaya, A.V.; Kotov, A.D.; Pozdniakov, A.V.; Portnoy, V.K. A high-strength aluminium-based alloy with advanced superplasticity. J. Alloy. Compd. 2014, 599, 139-144. [CrossRef]

30. Mikhaylovskaya, A.V.; Mochugovskiy, A.G.; Kotov, A.D.; Yakovtseva, O.A.; Gorshenkov, M.V.; Portnoy, V.K. Superplasticity of clad aluminium alloy. J. Mater. Process. Technol. 2017, 243, 355-364. [CrossRef]

31. Glazoff, M.V.; Khvan, A.V.; Zolotorevsky, V.S.; Belov, N.A.; Dinsdale, A.T. Industrial and Perspective Casting Alloys. In Casting Aluminum Alloys; Elsevier: Amsterdam, The Netherlands, 2019; pp. 405-510.

32. Pozdnyakov, A.V.; Osipenkova, A.A.; Popov, D.A.; Makhov, S.V.; Napalkov, V.I. Effect of Low Additions of Y, Sm, Gd, Hf and Er on the Structure and Hardness of Alloy Al-0.2\% Zr-0.1\% Sc. Met. Sci. Heat Treat. 2017, 58, 537-542. [CrossRef]

33. Wen, S.P.; Gao, K.Y.; Huang, H.; Wang, W.; Nie, Z.R. Precipitation evolution in Al-Er-Zr alloys during aging at elevated temperature. J. Alloy. Compd. 2013, 574, 92-97. [CrossRef]

34. Pozdniakov, A.V.; Barkov, R.Y.; Amer, S.M.; Levchenko, V.S.; Kotov, A.D.; Mikhaylovskaya, A.V. Microstructure, mechanical properties and superplasticity of the Al-Cu-Y-Zr alloy. Mater. Sci. Eng. A 2019, 758, 28-35. [CrossRef]

35. Rohrer, G.S. "Introduction to Grains, Phases, and Interfaces-An Interpretation of Microstructure," Trans. AIME, 1948, vol. 175, pp. 15-51, by C.S. Smith. Metall. Mater. Trans. A 2010, 41, 1063-1100. [CrossRef]

36. Humphreys, F.J. A unified theory of recovery, recrystallization and grain growth, based on the stability and growth of cellular microstructures-I. The basic model. Acta Mater. 1997, 45, 4231-4240. [CrossRef]

37. Humphreys, F.J. A unified theory of recovery, recrystallization and grain growth, based on the stability and growth of cellular microstructures-II. The effect of second-phase particles. Acta Mater. 1997, 45, 5031-5039. [CrossRef]

38. Manohar, P.A.; Ferry, M.; Chandra, T. Five Decades of the Zener Equation. ISIJ Int. 1998, 38, 913-924. [CrossRef]

39. Tolley, A.; Radmilovic, V.; Dahmen, U. Segregation in $\mathrm{Al}_{3}(\mathrm{Sc}, \mathrm{Zr})$ precipitates in Al-Sc-Zr alloys. Scr. Mater. 2005, 52, 621-625. [CrossRef]

40. Fuller, C.; Murray, J.; Seidman, D. Temporal evolution of the nanostructure of $\mathrm{Al}(\mathrm{Sc}, \mathrm{Zr}$ ) alloys: Part I-Chemical compositions of $\mathrm{Al}(\mathrm{ScZr})$ precipitates. Acta Mater. 2005, 53, 5401-5413. [CrossRef] 
41. Clouet, E. Excess solvent in precipitates. Nat. Mater. 2018, 17, 1060-1061. [CrossRef] [PubMed]

42. Yakovtseva, O.A.; Sitkina, M.N.; Kotov, A.D.; Rofman, O.V.; Mikhaylovskaya, A.V. Experimental study of the superplastic deformation mechanisms of high-strength aluminum-based alloy. Mater. Sci. Eng. A 2020, 788, 139639. [CrossRef]

43. Mochugovskiy, A.G.; Mikhaylovskaya, A.V. Comparison of precipitation kinetics and mechanical properties in Zr and Sc-bearing aluminum-based alloys. Mater. Lett. 2020, 275, 128096. [CrossRef]

44. Li, M.; Pan, Q.; Shi, Y.; Sun, X.; Xiang, H. High strain rate superplasticity in an Al-Mg-Sc-Zr alloy processed via simple rolling. Mater. Sci. Eng. A 2017, 687, 298-305. [CrossRef]

45. Lee, S.; Utsunomiya, A.; Akamatsu, H.; Neishi, K.; Furukawa, M.; Horita, Z.; Langdon, T. Influence of scandium and zirconium on grain stability and superplastic ductilities in ultrafine-grained Al-Mg alloys. Acta Mater. 2002, 50, 553-564. [CrossRef]

46. Kumar, A.; Mukhopadhyay, A.K.; Prasad, K.S. Superplastic behaviour of Al-Zn-Mg-Cu-Zr alloy AA7010 containing Sc. Mater. Sci. Eng. A 2010, 527, 854-857. [CrossRef]

47. Kaibyshev, R.; Avtokratova, E.; Apollonov, A.; Davies, R. High strain rate superplasticity in an Al-Mg-Sc-Zr alloy subjected to simple thermomechanical processing. Scr. Mater. 2006, 54, 2119-2124. [CrossRef]

48. Avtokratova, E.; Sitdikov, O.; Markushev, M.; Mulyukov, R. Extraordinary high-strain rate superplasticity of severely deformed Al-Mg-Sc-Zr alloy. Mater. Sci. Eng. A 2012, 538, 386-390. [CrossRef]

49. Dorin, T.; Ramajayam, M.; Babaniaris, S.; Langan, T.J. Micro-segregation and precipitates in as-solidified $\mathrm{Al}-\mathrm{Sc}-\mathrm{Zr}-(\mathrm{Mg})-(\mathrm{Si})-(\mathrm{Cu})$ alloys. Mater. Charact. 2019, 154, 353-362. [CrossRef]

50. Dorin, T.; Ramajayam, M.; Lamb, J.; Langan, T. Effect of Sc and Zr additions on the microstructure/strength of Al-Cu binary alloys. Mater. Sci. Eng. A 2017, 707, 58-64. [CrossRef]

51. Mochugovskiy, A.G.; Mikhaylovskaya, A.V.; Tabachkova, N.Y.; Portnoy, V.K. The mechanism of L12 phase precipitation, microstructure and tensile properties of Al-Mg-Er-Zr alloy. Mater. Sci. Eng. A 2019, 744, 195-205. [CrossRef]

52. Kotov, A.D.; Mikhaylovskaya, A.V.; Kishchik, M.S.; Tsarkov, A.A.; Aksenov, S.A.; Portnoy, V.K. Superplasticity of high-strength Al-based alloys produced by thermomechanical treatment. J. Alloy. Compd. 2016, 688, 336-344. [CrossRef]

53. Jingtao, W.; Qingling, W.; Jianzhong, C.; Haitao, Z. The Effect of Cerium on Superplasticity of AL-6CU-0.35 MG-0.2ZR Alloy. MRS Proc. 1990, 196, 283. [CrossRef]

54. Mikhaylovskaya, A.V.; Portnoy, V.K.; Mochugovskiy, A.G.; Zadorozhnyy, M.Y.; Tabachkova, N.Y.; Golovin, I.S. Effect of homogenisation treatment on precipitation, recrystallisation and properties of Al-3\% Mg-TM alloys ( $\mathrm{TM}=\mathrm{Mn}, \mathrm{Cr}, \mathrm{Zr}$ ). Mater. Des. 2016, 109, 197-208. [CrossRef]

55. Portnoy, V.K.; Rylov, D.S.; Levchenko, V.S.; Mikhaylovskaya, A.V. The influence of chromium on the structure and superplasticity of Al-Mg-Mn alloys. J. Alloy. Compd. 2013, 581, 313-317. [CrossRef]

56. Mochugovskiy, A.G.; Mikhaylovskaya, A.V.; Zadorognyy, M.Y.; Golovin, I.S. Effect of heat treatment on the grain size control, superplasticity, internal friction, and mechanical properties of zirconium-bearing aluminum-based alloy. J. Alloy. Compd. 2021, 856, 157455. [CrossRef]

57. Bate, P.S.; Humphreys, F.J.; Ridley, N.; Zhang, B. Microstructure and texture evolution in the tension of superplastic Al-6Cu-0.4Zr. Acta Mater. 2005, 53, 3059-3069. [CrossRef]

58. Mikhaylovskaya, A.V.; Yakovtseva, O.A.; Cheverikin, V.V.; Kotov, A.D.; Portnoy, V.K. Superplastic behaviour of Al-Mg-Zn-Zr-Scbased alloys at high strain rates. Mater. Sci. Eng. A 2016, 659, 225-233. [CrossRef]

59. Xiang, H.; Pan, Q.L.; Yu, X.H.; Huang, X.; Sun, X.; Wang, X.D.; Li, M.J.; Yin, Z.M. Superplasticity behaviors of Al-Zn-Mg-Zr cold-rolled alloy sheet with minor Sc addition. Mater. Sci. Eng. A 2016, 676, 128-137. [CrossRef]

60. Turba, K.; Málek, P.; Cieslar, M. Superplasticity in an Al-Mg-Zr-Sc alloy produced by equal-channel angular pressing. Mater. Sci. Eng. A 2007, 462, 91-94. [CrossRef]

61. Van Dalen, M.E.; Dunand, D.C.; Seidman, D.N. Effects of Ti additions on the nanostructure and creep properties of precipitationstrengthened Al-Sc alloys. Acta Mater. 2005, 53, 4225-4235. [CrossRef]

62. Belov, N.A.; Alabin, A.N.; Eskin, D.G.; Istomin-Kastrovskii, V.V. Optimization of hardening of Al-Zr-Sc cast alloys. J. Mater. Sci. 2006, 41, 5890-5899. [CrossRef]

63. Seidman, D.N.; Marquis, E.A.; Dunand, D.C. Precipitation strengthening at ambient and elevated temperatures of heat-treatable $\mathrm{Al}(\mathrm{Sc})$ alloys. Acta Mater. 2002, 50, 4021-4035. [CrossRef]

64. Mikhaylovskaya, A.V.; Mochugovskiy, A.G.; Levchenko, V.S.; Tabachkova, N.Y.; Mufalo, W.; Portnoy, V.K. Precipitation behavior of L12 Al3Zr phase in Al-Mg-Zr alloy. Mater. Charact. 2018, 139, 30-37. [CrossRef]

65. Mousavi Anijdan, S.H.; Kang, D.; Singh, N.; Gallerneault, M. Precipitation behavior of strip cast Al-Mg-0.4Sc-0.15Zr alloy under single and multiple-stage aging processes. Mater. Sci. Eng. A 2015, 640, 275-279. [CrossRef]

66. Guo, Z.; Zhao, G.; Chen, X.-G. Effects of two-step homogenization on precipitation behavior of Al3Zr dispersoids and recrystallization resistance in 7150 aluminum alloy. Mater. Charact. 2015, 102, 122-130. [CrossRef]

67. Yilin, S.; Li, C.; Yongchang, L.; Liming, Y.; Huijun, L. Intermetallic phase evolution and strengthening effect in Al-Mg2Si alloys with different $\mathrm{Cu} / \mathrm{Ni}$ ratios. Mater. Lett. 2018, 215, 254-258. [CrossRef]

68. Tonejc, A.; Ročák, D.; Bonefačić, A. Mechanical and structural properties of Al-Ni alloys rapidly quenched from the melt. Acta Metall. 1971, 19, 311-316. [CrossRef]

69. Suwanpreecha, C.; Toinin, J.P.; Michi, R.A.; Pandee, P.; Dunand, D.C.; Limmaneevichitr, C. Strengthening mechanisms in Al Ni Sc alloys containing Al3Ni microfibers and Al3Sc nanoprecipitates. Acta Mater. 2019, 164, 334-346. [CrossRef] 
70. Michi, R.A.; Toinin, J.P.; Seidman, D.N.; Dunand, D.C. Ambient- and elevated-temperature strengthening by Al3ZrNanoprecipitates and Al3Ni-Microfibers in a cast Al-2.9Ni-0.11Zr-0.02Si-0.005Er (at.\%) alloy. Mater. Sci. Eng. A 2019, 759, 78-89. [CrossRef]

71. Vo, N.Q.; Dunand, D.C.; Seidman, D.N. Improving aging and creep resistance in a dilute Al-Sc alloy by microalloying with Si, Zr and Er. Acta Mater. 2014, 63, 73-85. [CrossRef]

72. Dumbre, J.; Kairy, S.K.; Anber, E.; Langan, T.; Taheri, M.L.; Dorin, T.; Birbilis, N. Understanding the formation of (Al,Si)3Sc and V-phase (AlSc2Si2) in Al-Si-Sc alloys via ex situ heat treatments and in situ transmission electron microscopy studies. J. Alloys Compd. 2021, 861, 158511. [CrossRef]

73. Gifkins, R.C. Grain-Boundary Sliding and Its Accommodation during Creep and Superplasticity. Metall. Trans. A 1976, 7, 1225-1232. [CrossRef]

74. Yakovtseva, O.; Tomas, A.; Mikhaylovskaya, A. Surface and Internal Structural Markers for Studying Grain Boundary Sliding and Grain Rotation. Mater. Lett. 2020, 268, 127569. [CrossRef]

75. Myshlyaev, M.; Mironov, S.; Korznikova, G.; Konkova, T.; Korznikova, E.; Aletdinov, A.; Khalikova, G. EBSD Study of Superplastically Strained Al-Mg-Li Alloy. Mater. Lett. 2020, 275, 128063. [CrossRef]

76. Liu, X.; Ye, L.; Tang, J.; Shan, Z.; Ke, B.; Dong, Y.; Chen, J. Superplastic Deformation Mechanisms of an Al-Mg-Li Alloy with Banded Microstructures. Mater. Sci. Eng. A 2021, 805, 140545. [CrossRef]

77. Yasmeen, T.; Zhao, B.; Zheng, J.-H.; Tian, F.; Lin, J.; Jiang, J. The Study of Flow Behavior and Governing Mechanisms of a Titanium Alloy during Superplastic Forming. Mater. Sci. Eng. A 2020, 788, 139482. [CrossRef]

78. Zhu, Y.T.; Langdon, T.G. Influence of Grain Size on Deformation Mechanisms: An Extension to Nanocrystalline Materials. Mater. Sci. Eng. A 2005, 409, 234-242. [CrossRef]

79. Valiev, R.Z.; Salimonenko, D.A.; Tsenev, N.K.; Berbon, P.B.; Langdon, T.G. Observations of High Strain Rate Superplasticity in Commercial Aluminum Alloys with Ultrafine Grain Sizes. Scr. Mater. 1997, 37, 1945-1950. [CrossRef] 